\title{
Opportunities and limitations related to the application of plant-derived lipid molecular proxies in soil science
}

\author{
Boris Jansen $^{1}$ and Guido L. B. Wiesenberg ${ }^{2}$ \\ ${ }^{1}$ Institute for Biodiversity and Ecosystem Dynamics, P.O. Box 94240, University of Amsterdam, $1090 \mathrm{GE}$ \\ Amsterdam, the Netherlands \\ ${ }^{2}$ Department of Geography, University of Zürich, Winterthurerstrasse 190, 8057 Zurich, Switzerland
}

Correspondence to: Boris Jansen (b.jansen@uva.nl)

Received: 14 March 2017 - Discussion started: 20 April 2017

Revised: 14 August 2017 - Accepted: 24 September 2017 - Published: 16 November 2017

\begin{abstract}
The application of lipids in soils as molecular proxies, also often referred to as biomarkers, has dramatically increased in the last decades. Applications range from inferring changes in past vegetation composition, climate, and/or human presence to unraveling the input and turnover of soil organic matter (SOM). The molecules used are extractable and non-extractable lipids, including ester-bound lipids. In addition, the carbon or hydrogen isotopic composition of such molecules is used. While holding great promise, the application of soil lipids as molecular proxies comes with several constraining factors, the most important of which are (i) variability in the molecular composition of plant-derived organic matter both internally and between individual plants, (ii) variability in (the relative contribution of) input pathways into the soil, and (iii) the transformation and/or (selective) degradation of (some of) the molecules once present in the soil. Unfortunately, the information about such constraining factors and their impact on the applicability of molecular proxies is fragmented and scattered. The purpose of this study is to provide a critical review of the current state of knowledge with respect to the applicability of molecular proxies in soil science, specifically focusing on the factors constraining such applicability. Variability in genetic, ontogenetic, and environmental factors influences plant $n$-alkane patterns in such a way that no unique compounds or specific molecular proxies pointing to, for example, plant community differences or environmental influences, exist. Other components, such as $n$-alcohols, $n$-fatty acids, and cutin- and suberin-derived monomers, have received far less attention in this respect. Furthermore, there is a high diversity of input pathways offering both opportunities and limitations for the use of molecular proxies at the same time. New modeling approaches might offer a possibility to unravel such mixed input signals. Finally, the transformation and turnover of SOM offer opportunities when tracing such processes is the purpose of applying a molecular proxy while imposing limitations when they obliterate the molecular proxy signals linked to other phenomena. For $n$-alkanes several modeling approaches have recently been developed to compensate for (selective) degradation. Still, such techniques are in their infancy and information about their applicability to classes of components other than $n$-alkanes is lacking. All constraining factors considered can have a significant influence on the applicability of molecular proxies in soil science. The degree of influence strongly depends on the type of molecular proxy and the environmental context in which it is applied. However, the potential impact of the constraining factors should always explicitly be addressed whenever molecular proxies are applied in a soil scientific context. More importantly, there is still a serious lack of available information, in particular for compound classes other than the $n$-alkanes. Therefore, we urgently call for the consideration of more holistic approaches determining various factors during sampling and using as many compound classes as possible.
\end{abstract}




\section{Introduction}

For more than a century, various compounds deriving from the substance class of lipids have been investigated in plant and soil science. Some of the earliest publications in plant science date back to the first half of the 19th century (Liebig et al., 1837; Wöhler and Liebig, 1839) and in soil science to the early 20th century as reviewed by Stevenson (1966). One of the main interests to study lipids was the large heterogeneity of compounds included in this substance class. Some of the individual compounds have been described as "biomarkers" or "biogenic markers", i.e., compounds that "may be diagnostic of specific organisms, classes of organism, or general biota that contribute organic matter to the atmosphere, aqueous or sedimentary environment" (Peters et al., 2005). In addition, in environmental sciences, anthropogenic and petroleum markers were also highlighted that have the ability to be preserved with "no or only minor change" (Tissot and Welte, 1984; Peters et al., 2005). Because the term biomarker has been used in a narrow sense for the differentiation of biological tissues of different origin in environmental matrices, recently the term "molecular proxy" has come into vogue. This term allows for the inclusion of biomarkers as individual compounds characterizing specific biogenic sources, but also individual compounds acting as a specific proxy (e.g., for anthropogenic impact or thermal alteration). Furthermore, it accommodates the use of groups of compounds used in the before-mentioned way. Finally, it implies the use of molecular ratios of compounds like the carbon preference index (CPI) or the average chain length (ACL) that could also be indicative for biogenic sources, alteration, or overprint of organic matter. Therefore, in the present work we use the term molecular proxy rather than biomarker.

In the broadest sense, molecular proxies allow for the determination of the presence, absence, or certain characteristics of a (set of) molecule(s) that are indicative of a process in or the state or composition of a system of interest. For instance, in the clinical sciences molecular proxies among other applications are used as indicators of the presence of a disease or response to treatment (Brennan et al., 2013; Van Bon et al., 2014). In toxicology they are used to assess the effect of toxicant exposure on biota (Clemente et al., 2014), and in the forensic sciences they can link suspects to a crime scene (Concheri et al., 2011). In limnology they are used to examine past lacustrine environmental conditions (Castañeda and Schouten, 2011), and in organic geochemistry they can be used to follow oil formation and translocation in source and reservoir rocks (Curiale, 2002).

Also in soil science, molecular proxies have been used for decades, and their application has exponentially increased in the last decade as indicated by the number of related articles published in Web of Science indexed journals (Table 1). The types of molecular proxies used are as diverse as the field of soil science itself. They range from the use of phospholipid fatty acids to estimate bacterial and fungal biomass in soils (Frostegard and Bååth, 1996) to the application of preserved retene/ caldalene ratios to infer paleoecological vegetation shifts (Hautevelle et al., 2006). Also, the archives of the molecular proxies in soil sciences that are used are diverse and, in addition to soils themselves, include lacustrine and terrestrial sediments, peat deposits, and paleosols (Zhang et al., 2006; Bai et al., 2009; Andersson et al., 2011; Berke et al., 2012). However, in spite of this large variety a limited number of scientific topics can be discerned that encompass the great majority of molecular proxy application in the soil sciences. These are outlined as follows:

- changes in vegetation composition inferred from extractable and/or ester-bound lipids of plant origin and/or their carbon isotopic composition (e.g., Huang et al., 1996; Zech et al., 2009a; Le Milbeau et al., 2013);

- changes in climate, i.e., mean annual temperature and/or precipitation inferred from bacterial membrane lipids and/or the hydrogen isotopic composition of plantderived lipids (e.g., Weijers et al., 2006; Krull et al., 2006; Rao et al., 2009);

- changes in paleo-elevation inferred from bacterial membrane lipids and/or the hydrogen isotopic composition of plant-derived lipids (e.g., Sachse et al., 2006; Bai et al., 2011; Ernst et al., 2013);

- changes in human impact or settlement inferred from compound-specific $\mathrm{N}$-isotope analysis or transformation products of plant-derived lipids, e.g., through burning or manure-derived lipids (e.g., Bull et al., 1999; Eckmeier and Wiesenberg, 2009; Zocatelli et al., 2012);

- and the contribution of fossil-fuel-derived carbon to soil assessed according to lipid molecular composition and compound-specific isotopes (e.g., Lichtfouse et al., 1995, 1997; Rethemeyer et al., 2004).

Input, transformation and/or decomposition of soil organic matter inferred from or traced through extractable and/or ester-bound lipids of plant origin and/or bacterial membrane lipids and/or their carbon isotopic composition. (e.g., Nierop et al., 2001; Amelung et al., 2008; Hamer et al., 2012).

In Table 1 an overview is given of the classes of molecules frequently used as molecular proxies in soil archives in relation to their application and total and recent (last 10 years) publications including the respective keywords.

When using molecular proxies to answer research questions in any of the areas identified, in particular when soils are used as an archive, several constraining factors have to be taken into account that vary with the type of application and research question to be answered. The most important ones are the following:

i. variability in the source of plant-derived organic matter, i.e., the abundance and composition of the molecular 
Table 1. Compounds frequently used as molecular proxies in soils.

\begin{tabular}{|c|c|c|c|}
\hline $\begin{array}{l}\text { Compound (the ones } \\
\text { considered in this review } \\
\text { indicated in bold) }\end{array}$ & $\begin{array}{l}\text { Most commonly } \\
\text { used as a proxy for }\end{array}$ & $\begin{array}{l}\text { Examples of } \\
\text { recent } \\
\text { publications }^{\mathrm{a}}\end{array}$ & $\begin{array}{l}\text { Number of articles } \\
\text { published until } 2017 \\
\text { (publications 2007- } \\
2016)^{\text {b }}\end{array}$ \\
\hline \multicolumn{4}{|c|}{ Molecules of plant origin } \\
\hline $\begin{array}{l}n \text {-Alkanes, } n \text {-alcohols } \\
(n \text {-alkanol }), n \text {-fatty } \\
\text { acids }(n \text {-alkanoic acid })\end{array}$ & $\begin{array}{l}\text { (Groups of) plant } \\
\text { species }\end{array}$ & $\begin{array}{l}\text { Zhang et al. (2006), Zeng et } \\
\text { al. (2011), } \\
\text { Jansen et al. } \\
\text { (2013), Gocke } \\
\text { et al. (2013) }\end{array}$ & $\begin{array}{l}n \text {-Alkane: } 1588(1025) \\
n \text {-Alcohol: } 1972(1123) \\
n \text {-Alkanol: } 18(11) \\
n \text {-Fatty acids: } 43(27) ; \\
n \text {-Alkanoic acid: } 67(41)\end{array}$ \\
\hline n-Methyl ketones & $\begin{array}{l}\text { Degradation/ } \\
\text { transformation } \\
\text { of soil organic } \\
\text { matter }\end{array}$ & $\begin{array}{l}\text { Bai et al. } \\
\text { (2006), Jansen } \\
\text { and Nierop } \\
\text { (2009), B. K. Lei } \\
\text { et al. (2010) }\end{array}$ & n-Methyl ketone 104 (50) \\
\hline $\begin{array}{l}\text { Plant sterols and } \\
\text { pentacyclic } \\
\text { triterpenoids }\end{array}$ & $\begin{array}{l}\text { (Groups of) plant } \\
\text { species }\end{array}$ & $\begin{array}{l}\text { Volkman } \\
\text { (2005), Jansen } \\
\text { et al. (2007), } \\
\text { Lavrieux et } \\
\text { al. (2011) }\end{array}$ & $\begin{array}{l}\text { Plant sterol: } 1682(590) \\
\text { Pentacyclic triterpenoid: } \\
25(10)\end{array}$ \\
\hline Lignin monomers & $\begin{array}{l}\text { Coniferous species } \\
\text { versus broadleaf } \\
\text { species versus grasses } \\
\text { and organic matter } \\
\text { transformation }\end{array}$ & $\begin{array}{l}\text { Nierop et al. } \\
\text { (2006), Heim } \\
\text { and Schmidt } \\
\text { (2007), } \\
\text { Thevenot et } \\
\text { al. (2010), } \\
\text { Simpson and } \\
\text { Simpson } \\
\text { (2012), Moingt } \\
\text { et al. (2016) }\end{array}$ & Lignin monomer: $115(74)$ \\
\hline $\begin{array}{l}\text { Cutin and suberin } \\
\text { monomers }\end{array}$ & $\begin{array}{l}\text { Root versus } \\
\text { aboveground } \\
\text { biomass input }\end{array}$ & $\begin{array}{l}\text { (Mendez- } \\
\text { Millan et al. } \\
\text { (2011), Hamer } \\
\text { et al. (2012) }\end{array}$ & $\begin{array}{l}\text { Cutin monomer: } 25(17) \\
\text { Suberin monomer: } 32(18)\end{array}$ \\
\hline
\end{tabular}

\begin{tabular}{|c|c|c|c|}
\hline \multicolumn{4}{|c|}{ Molecules of animal or bacterial origin } \\
\hline $\begin{array}{l}\text { Manure compounds } \\
\text { such as coprostanol, } \\
5 \beta \text {-stigmastanol, } \\
\text { sitosterol, and their } \\
\text { epimers }\end{array}$ & $\begin{array}{l}\text { Human impact, } \\
\text { animal husbandry }\end{array}$ & $\begin{array}{l}\text { D'Anjou et } \\
\text { al. (2012), } \\
\text { Birk et al. } \\
\text { (2012), Prost et } \\
\text { al. (2017) }\end{array}$ & $\begin{array}{l}\text { Coprostanol: } 35(17) \\
\text { Stigmastanol: } 12(7) \\
\text { Sitosterol: } 70(47)\end{array}$ \\
\hline $\begin{array}{l}\text { Glycerol dialkyl glycerol } \\
\text { tetraethers (GDGTs) }\end{array}$ & $\begin{array}{l}\text { Mean ambient air } \\
\text { temperature, paleo- } \\
\text { elevation and soil } \\
\text { pH }\end{array}$ & $\begin{array}{l}\text { Luo et al. } \\
\text { (2011), } \\
\text { Weijers et al. } \\
\text { (2011), Peterse } \\
\text { et al. (2012), } \\
\text { Ernst et al. } \\
\text { (2013), De } \\
\text { Jonge et al. } \\
\text { (2014) }\end{array}$ & GDGT: 148 (144) \\
\hline
\end{tabular}


Table 1. Continued.

\begin{tabular}{|c|c|c|c|}
\hline $\begin{array}{l}\text { Compound (the ones } \\
\text { considered in this review } \\
\text { indicated in bold) }\end{array}$ & $\begin{array}{l}\text { Most commonly } \\
\text { used as a proxy for }\end{array}$ & $\begin{array}{l}\text { Examples of } \\
\text { recent } \\
\text { publications }^{\mathrm{a}}\end{array}$ & $\begin{array}{l}\text { Number of articles } \\
\text { published until } 2017 \\
\text { (publications 2007- } \\
2016)^{\mathrm{b}}\end{array}$ \\
\hline \multicolumn{4}{|c|}{ Molecules of animal or bacterial origin } \\
\hline $\begin{array}{l}\text { Phospholipid fatty acids } \\
\text { (PLFAs) }\end{array}$ & Microbial biomass & $\begin{array}{l}\text { Kramer and } \\
\text { Gleixner } \\
\text { (2006), Kindler } \\
\text { et al. (2009), } \\
\text { Ngosong et } \\
\text { al. (2012), } \\
\text { Malik et al. } \\
\text { (2013) }\end{array}$ & $\begin{array}{l}\text { Phospholipid fatty acid: } \\
2157(1628) \\
\text { PLFA: } 1525(1140)\end{array}$ \\
\hline \multicolumn{4}{|c|}{ Compound-specific stable isotope signal of one or more of the above $\mathrm{c}^{\mathrm{c}}$} \\
\hline$\delta^{13} \mathrm{C}$ & $\begin{array}{l}\mathrm{C}_{3} \text { versus } \mathrm{C}_{4} \text { plants } \\
\text { and tracing carbon } \\
\text { transformations, } \\
\text { e.g., by free-air } \mathrm{CO}_{2} \\
\text { enrichment } \\
\text { (FACE) }\end{array}$ & $\begin{array}{l}\text { Feng et al. } \\
(2010), \\
\text { Mendez- } \\
\text { Millan et al. } \\
(2012)\end{array}$ & ${ }^{13} \mathrm{C}: 13(11)$ \\
\hline$\delta^{15} \mathrm{~N}$ & $\begin{array}{l}\text { (Past) land } \\
\text { management }\end{array}$ & $\begin{array}{l}\text { Bol et al. } \\
(2005) \\
\text { Griepentrog } \\
\text { et al. (2014) }\end{array}$ & ${ }^{15} \mathrm{~N}: 2(2)$ \\
\hline$\delta^{2} \mathrm{H}$ (deuterium) & $\begin{array}{l}\text { Precipitation and } \\
\text { paleo-elevation }\end{array}$ & $\begin{array}{l}\text { Peterse et } \\
\text { al. (2009), Bai } \\
\text { et al. (2011), } \\
\text { Luo et al. } \\
\text { (2011), Sachse } \\
\text { et al. (2012), } \\
\text { Hermann et } \\
\text { al. (2017) }\end{array}$ & $\begin{array}{l}{ }^{2} \mathrm{H}: 6(4) \\
\text { Deuterium: } 9 \text { (7) }\end{array}$ \\
\hline$\Delta^{14} \mathrm{C}$ (radiocarbon) & $\begin{array}{l}\text { Age and } \\
\text { contamination } \\
\text { determination }\end{array}$ & $\begin{array}{l}\text { Marschner et } \\
\text { al. (2008), } \\
\text { Mendez- } \\
\text { Millan et al. } \\
\text { (2014) }\end{array}$ & $\begin{array}{l}{ }^{14} \mathrm{C}: 3(1) \\
\text { Radiocarbon: } 35 \text { (30) }\end{array}$ \\
\hline
\end{tabular}

a Published from 2005 until 2017. b According to ISI Web of Science, checked for "soil" and "target compound" in the topics of articles on 27 February 2017 included in all available databases. " "Compound-specific" and the respective isotope (i.e., ${ }^{13} \mathrm{C},{ }^{15} \mathrm{~N},{ }^{2} \mathrm{H}$, and ${ }^{14} \mathrm{C}$ ) were used as separate keywords in addition to "soil".

proxies in different plant species, plant specimens, and plant parts as a result of genetic or life stage variations and/or external factors such as climate, seasonality, or exposure to the sun (e.g., Nødskov Giese, 1975; Lockheart et al., 1998; Shepherd and Griffiths, 2006);

ii. variability in (the relative contribution of) input pathways into the soil, in particular microbial versus vegetation input and root versus aboveground biomass input (e.g., Jackson et al., 1996; Schefuß et al., 2003; Mambelli et al., 2011); iii. and the transformation and/or (selective) degradation of (some of) the compounds once present in the soil when it is not the aim of the study to use the molecular proxies to study such transformations (e.g., De Leeuw and Baas, 1986; Nguyen Tu et al., 2004; Andreetta et al., 2013).

However, the information about such constraining factors and their impact on the applicability of molecular proxies is fragmented and scattered over different publications inside and outside the discipline of soil sciences. For instance, much of the available information about variation in leaf wax 
lipid composition is presented in the plant physiological literature in studies that were not conducted with the application of such lipids as a molecular proxy for past vegetation composition from soil archives in mind (e.g., Tulloch, 1973; Avato et al., 1984; Kim et al., 2007). The fragmentation of the information makes it difficult for researchers to assess the potential influence of constraining factors on the application of molecular proxies. It also hinders the identification of hiatuses in the available knowledge about the constraining factors and the designation of potential strategies to compensate or correct for such constraints.

Therefore, the purpose of the present study is to provide a critical review of the current state of knowledge with respect to the applicability of molecular proxies in soil science, specifically focusing on the factors constraining such applicability. Based on this we will identify areas for future research both with respect to the application of molecular proxies in soil science and the constraints thereof.

The vastness of the field of molecular proxies forced us to restrict the scope of the present study. With respect to the molecules to consider, a first restriction was to focus on those related to the earlier-mentioned main areas of application for molecular proxies in soil science. A second restriction was to focus on the main classes of components as used by several researchers. Finally, in spite of their common application, we explicitly excluded lignin and phospholipid fatty acids (PLFAs) as lignin was the subject of another recent review (Thevenot et al., 2010) and PLFAs are considered in such a large set of studies (cf. Table 1) that they would require a separate review. Finally, GDGTs were excluded because their application is predominantly in aquatic sediments rather than soils and they have been recently reviewed (Schouten et al., 2013). This leaves the component classes labeled in bold in Table 1 to be considered in the present study. Our study is relevant to the application of compound-specific isotope analysis inasmuch as such analysis is directly affected by the variability and transformation of the underlying molecules. However, we did not explicitly consider the sources and effects of variation in the stable $\delta^{13} \mathrm{C}$ and $\delta^{2} \mathrm{H}$ isotope signature of specific molecules themselves; this is a research area of its own and also the subject of other recent reviews by Sachse et al. (2012) and Diefendorf and Freimuth (2017). Furthermore, when considering the application and preservation of molecular proxies we restricted ourselves to topsoils as archives (i.e., surface soil horizons or A horizons as defined by the FAO in the Guidelines for Soil Description; FAO, 2006).

\section{Source-related variability of molecular proxies}

\subsection{Definition}

Source-related variability in molecular proxies pertains to intraspecies variation in the abundance of the molecules that are used as a proxy. Such variability entails (i) variation in the relative abundance of individual compounds that together constitute the proxy, e.g., $n$-alkanes of different chain lengths in the leaf waxes of a certain species and (ii) variation in the absolute abundance of the molecules used as a proxy either between different specimens or between different parts of a single specimen. Depending on the research question, intraspecies variability in molecular proxies may be desirable or not. For instance, when preserved leaf wax lipid patterns are used to reconstruct past vegetation composition, the implicit assumption is that the intraspecies variability in the source vegetation is small compared to the interspecies variability.

There are two main causes of intraspecies variability in molecular proxies: internal variation related to genetics and/or ontogeny and external variation related to the growing environment. Both are related in the sense that differences in the response to environmental factors are also often genetically determined (Shepherd and Griffiths, 2006). Here we discuss both causes separately with a third paragraph devoted to studies in which combined effects were examined. For a detailed description of the biomolecular mechanisms of wax genesis and all potential sources of change, the reader is referred to the review provided by Shepherd and Griffiths (2006).

\subsection{Variation related to genetics and/or ontogeny}

\subsubsection{Wax lipids}

Many studies have indicated that the clear genetic control of leaf wax genesis leads to a significant and meaningful difference in their composition (Shepherd et al., 1995; Shepherd and Griffiths, 2006). For instance, prompted by the early work in this area (e.g., Eglinton et al., 1962a, b; Herbin and Robins, 1968, 1969), Maffei performed an extensive evaluation of the $n$-alkane patterns in several hundred plant species belonging to the Poaceae, Apiaceae, Brassicaceae, Fabaceae, Cactaceae, Pinaceae, Lamiaceae, Boraginaceae, Verbenaceae, Solanaceae, and Scrophulariaceae (Maffei, 1994, 1996a, b; Maffei et al., 1997, 2004). These studies were replenished by those on Styracaceae (Li et al., 2013), Moraceae (Sonibare et al., 2005), and Clusiaceae (Medina et al., 2004, 2006). Further, Dove et al. (1996) described the alkane diversity among a grassland plant community, which enables the tracing of the diet of grazing animals due to the different alkane compositions of the plants. Recently, Mueller-Niggemann and Schwark (2015) were able to differentiate rice from alternating crop plants based on their $n$-alkane patterns. The results support the chemotaxonomic discriminatory power of $n$-alkane patterns at family, subfamily, and tribal level, which has been further examined by Diefendorf and Freimuth (2017). Examining plant $n$-alkane and $n$-alcohol distribution of $37 \mathrm{C}_{4}$ grasses, Rommerskirchen et al. (2006) also found that chemotaxonomic differentiation was possible at the subfamily level. Mongrand et al. (2001) examined the fatty acid composition of 
the leaves of over 137 species of gymnosperms belonging to 14 families collected from different locations in France. They found a taxonomically meaningful clustering into four main groups, with the highest discriminatory power in the Pinaceae at the genus level (Mongrand et al., 2001). Additionally, Wiesenberg and Schwark (2006) determined differences in the fatty acid composition between temperate $\mathrm{C}_{3}$ and $\mathrm{C}_{4}$ crops. Within the same Brassica species of kale and swede, Shepherd et al. (1995) observed a difference in the chain length distribution of wax lipids between two genotypes of the same species, which is indicative of genetic control through variation in the enzyme system. Also for the isoprenoids, a genetically driven discriminatory power related to (groups of) plant species is attributed (Ohsaki et al., 1999; Jansen et al., 2007).

The chemotaxonomic potential of wax lipids as just described has been exploited to reconstruct past vegetation history from wax lipids preserved in soil archives (e.g., Bull et al., 1999; Zech et al., 2009a; Jansen et al., 2013). Such reconstructions often focus on the use of shifts in the ratios of certain dominant higher chain length $n$-alkanes, fatty acids, and $n$-alcohols representative of a shift in the dominant vegetation over time (Jansen et al., 2010; Gocke et al., 2016; Wiesenberg et al., 2015). In a few instances, the entire suite of higher chain length $n$-alkanes and $n$-alcohols (Jansen et al., 2013) or $n$-alkanes and fatty acids has also been used (Wiesenberg et al., 2015).

However, in addition to other issues such as those discussed in the other sections of this review, an important issue when exploiting the chemotaxonomic potential of leaf wax lipids is the phenotypic plasticity of the genetic variability in leaf wax lipid patterns found and the implications thereof for the stability of the patterns observed. Maffei et al. (2004) concluded that phenotypic plasticity may overcome genetic variability, particularly when plant developmental stages are considered along with abiotic and biotic stress conditions. Several plant physiological studies have focussed on wax lipid composition related to plant life stage and report different results. Avato et al. (1984) found that where the relative contribution of $n$-fatty acids, $n$-alcohols, and $n$-alkanes differed between Sorghum seedlings and mature leaves, the chain length distribution within a component class remained the same for the $n$-alkanes and $n$-alcohols. Giese (1975) observed a difference in the homologue dominance of $n$-alkanes between leaves of seedlings and mature barley plants. Herbin and Robins (1969), Dyson and Herbin (1970), Baker and Hunt (1981), and Zhang et al. (2004) also identified increasing chain length dominance of leaf wax alkanes with increasing leaf age. However, the averaging of sampling over leaves of different ages, positions, and other characteristics within a stand of trees did allow for distinction from other stands, indicating that interspecies variation was larger than intraspecies variation (Dyson and Herbin, 1970). Baker and Hunt (1981) observed differences between the adaxial and abaxial parts of leaves for some of the plant species. Tul- loch (1973) also observed variation in the leaf waxes of several Triticum species with age. In particular, the whole plant $n$-alkane predominance shifted from $\mathrm{C}_{31}$ at 24 days after germination to $\mathrm{C}_{29}$ at 100 days after germination (Tulloch, 1973). Furthermore, Wiesenberg et al. $(2004,2012)$ and Wiesenberg and Schwark (2006) observed changes in the $n$ alkane and $n$-fatty acid compositions of a variety of temperate crop species with plant age. Other publications reported seasonal variations in the $n$-alkane composition for a variety of pasture and crop plants (Dove et al., 1996; Hellgren and Sandelius, 2001; Moseley, 1983; Shelvey and Koziol, 1986) and various trees (Prasad and Gülz, 1990; Gülz et al., 1991; Gülz and Muller, 1992; Gülz and Boor, 1992). Variations in the $n$-alkane composition could be observed during the growing season among all investigated plants, but general trends of increasing or decreasing chain length and $n$-alkane contents have not consistently been determined. The $n$-alcohol predominance also varied but to a much smaller extent, not affecting the predominance of a specific $n$-alcohol (Tulloch, 1973). Esters gradually showed an increase in esters of trans 2,3-unsaturated $\mathrm{C}_{23}$ and $\mathrm{C}_{24}$ acids with plant age (Tulloch, 1973). The variation was related to the development of the plant, in particular that of flag leaves and sheets between 55 and 66 days (Tulloch, 1973).

In contrast to previous studies, $\mathrm{Li}$ et al. (1997) studied the influence of ontogeny on leaf wax lipids ( $n$-alkanes, $n$ aldehydes, $n$-alcohols, esters, $\beta$-diketones, flavonoids, and triterpenoids) in several Eucalyptus species of the subgenus Symphyomyrtus on Tasmania and found no significant effect of ontogeny on leaf wax composition, which they found to clearly and consistently differ between species ( $\mathrm{Li}$ et al., 1997). Eglinton et al. (1962a) also observed that the $n$-alkane composition of the leaf waxes of 74 species of Crassulaceae from the Canary Islands showed no appreciable variation with respect to leaf position, age, size, or specimen. Further, Bush and McInerney (2013) found no influence of canopy position or sampling time on the $n$-alkane patterns of mature leaves from 24 tree species.

\subsubsection{Cutin and suberin monomers}

Cutin and suberin monomers are mainly used as proxies to distinguish leaf from root input in soils (Schreiber et al., 1999; Bull et al., 2000; Mendez-Millan et al., 2011) or as a proxy for related phenomena such as the degree of bioturbation in the topsoil (Nierop and Verstraten, 2004). Therefore, the possible (onto)genetic effects on cutin and suberin composition are a concern if they were to alter the composition of the polyesters to such an extent that the separation between cutin and suberin is compromised.

Some general observations in the literature are that longchain even-numbered $\mathrm{C}_{20}-\mathrm{C}_{30} \omega$-hydroxy fatty acids and $\alpha$ - and $\omega$-alkanediotic acids mainly originate from suberin, whereas shorter-chained $\mathrm{C}_{16}$ and $\mathrm{C}_{18} \omega$-hydroxy fatty acids mainly derive from cutin (Schreiber et al., 1999; Otto et al., 
2005; Mendez-Millan et al., 2011). However, several publications challenge the universal applicability of such general observations, indicating instead that genetic variability results in many exceptions to such general rules. For instance, Hamer et al. (2012) found that $\omega \mathrm{C}_{22: 0}, \omega \mathrm{C}_{24: 0}$, and $\omega \mathrm{C}_{26: 0}$ hydroxy fatty acids were not exclusively associated with roots, but also occurred in the shoots of several species. In addition, $\omega \mathrm{C}_{16: 0}$ and $\omega \mathrm{C}_{18: 0}$ fatty acids were not exclusive to the leaves, but also occurred in the roots of several species.

\subsection{Variation related to environmental factors}

\subsubsection{Effects of temperature}

Increased solar radiation levels are generally reported to lead to higher absolute amounts of waxes produced (Sanchez et al., 2001; Shepherd and Griffiths, 2006). In addition, the composition of the various component classes of wax lipids, i.e., the relative contribution of $n$-fatty acids, $n$-alkanes, and $n$-alcohols, has been reported to change. A shift towards lower chain lengths within different component classes was sometimes found (Shepherd and Griffiths, 2006). Thus, a positive correlation of long-chain odd $n$-alkanes with temperature was observed (Maffei et al., 1993; Zhang et al., 2004). Also, the abundance of membrane fatty acids with 16 and 18 carbons can change as a result of temperature (Maffei et al., 1993; Williams et al., 1995; Matteucci et al., 2011). Under heat stress, the relative abundance of $C_{16: 0}$ fatty acid was often found to increase, and the abundance of polyunsaturated $\mathrm{C}_{18: 3}$ fatty acid was found to decrease (Larkindale and Huang, 2004; Bakht et al., 2006). Furthermore, effects of temperature were observed for monoterpenes and sesquiterpenes, with compounds like limonene and myrcene having a close correlation with temperature, whereas others like 1,8cineol were not affected by temperature (Maffei et al., 1993). As a cause, different sensitivities of individual steps in the genesis of the wax lipid components are assumed (Shepherd and Griffiths, 2006). However, results were found to vary between different species and genotypes, indicating a species- or genotype-related sensitivity to changes in irradiation (Shepherd and Griffiths, 2006), whereas cold- or heatacclimated plants respond differently than those that are not acclimated (Larkindale and Huang, 2004). Thus, a dependency between temperature and lipid metabolism is widely observed, but, especially in plants, other factors such as humidity or greenhouse gas composition might coincide with a larger effect on the overall lipid composition.

In addition to the effect of temperature on lipid synthesis, temperature can also influence lipids after production specifically as a result of fire. This topic is addressed in Sect. 4.2.

\subsubsection{Effects of humidity}

With respect to the effects of water stress and/or high humidity, Shepherd and Griffith (2006) reported mixed results in their review with respect to absolute amounts and chain length distribution. Bondada et al. (1996) reported an increase in absolute amounts of epicuticular wax production by $69 \%$ in the leaves of cotton (Gossypium hirsutum) under water stress, which was confirmed by Hamrouni et al. (2001), Koch et al. (2006), Kim et al. (2007), and Bettaieb et al. (2010) for neutral lipids of other plant species. However, Kim et al. (2007) found that water stress had only a minor effect on chain length distribution. The relative contribution of different component classes to the wax composition remained unchanged except for Brassica oleracea var. gongylodes at the highest relative humidity, which showed an increased contribution of ketones and primary alcohols and a reduction of secondary alcohols and aldehydes (Koch et al., 2006). Recently, Srivastava et al. (2017) determined that sustained effects of drought on plant lipid composition are commonly missing with few exceptions for perennial plants. Thus, several months after exposure to drought the lipid biosynthesis and composition of leaves is resilient. The existing data show that the general effects of drought on plant lipid composition are difficult to infer.

\subsubsection{Effects of increased $\mathrm{CO}_{2}$}

Changes in greenhouse gases such as $\mathrm{CO}_{2}$ have also been discussed as influencing the lipid biosynthesis and thus the lipid composition of plants. Short-term exposure of several hours to elevated $\mathrm{CO}_{2}$ concentrations, e.g., during ${ }^{13} \mathrm{CO}_{2}$ or ${ }^{14} \mathrm{CO}_{2}$ labeling experiments, has little to no effect on lipid composition, especially if sampling occurs several days after labeling (Wiesenberg et al., 2009). In contrast, a long-term rise in atmospheric $\mathrm{CO}_{2}$ concentration has been investigated in laboratory or free-air carbon dioxide enrichment (FACE) experiments (Ainsworth and Long, 2005). Although numerous such experiments have been conducted in the meantime, the investigation of lipid composition is limited. Greenhouse experiments showed that elevated $\mathrm{CO}_{2}$ concentration affects the relative composition of saturated and unsaturated fatty acids in wheat plants (Williams et al., 1994, 1995, 1998). However, rising nitrogen fertilization and rising temperature can lead to competing trends (Williams et al., 1995; Griepentrog et al., 2016). Although specific abundances of individual long-chain alkanes and alcohols changed under elevated $\mathrm{CO}_{2}$ concentration, the overall lipid composition expressed as ACL and CPI did not change (Huang et al., 1999). Nevertheless, concentration changes, like an increase in $n$-alkane and $n$-alcohol abundances and a decrease in $n$-fatty acid abundance, were determined under a rising $\mathrm{CO}_{2}$ concentration, whereas nitrogen fertilization led to a decrease in the effect (Huang et al., 1999). This was confirmed by Wiesenberg et al. (2008a) for $n$-alkanes, $n$-fatty acids, and $n$-alcohols. In some forest FACE and open-top chamber experiments, the effects of elevated $\mathrm{CO}_{2}$ on plant lipid concentration were not identified (Feng et al., 2010; Griepentrog et al., 2015), but the ${ }^{13} \mathrm{CO}_{2}$ labeling associated with the $\mathrm{CO}_{2}$ enrichment was 
used for tracing the turnover of lipids in soils as introduced by Wiesenberg et al. (2008b).

\subsection{Other or combined genetic, ontogenetic, and/or environmental effects}

Many studies considered the effects of geographical location on wax amounts and/or composition without differentiating between individual genetic or environmental causes. Again, the exact parameters investigated vary greatly between studies, as do the conclusions drawn. Cowlishaw et al. (1983) examined the $n$-alkane, $n$-alcohol, $n$-aldehyde, and ester composition of composite samples of four species of the Poaceae Chionochloa, one of which was sampled at three different environmental locations to investigate environmental effects. They found distinct chain length patterns that allowed for chemotaxonomic identification, and variation between the three sampling sites did not alter the dominant chain length patterns for any of the component classes (Cowlishaw et al., 1983). Similar observations were made by Herbin and Sharma (1969) for the $\omega$-hydroxy fatty acid composition of Pinus species from Asia, Europe, North America, Central America, and the Caribbean. Kreyling et al. (2012) described differences in the $n$-fatty acid and $n$-alkane composition of the same plant species originating from different regions across Europe with different climatic conditions that are most likely due to biosynthetic adaptation to the specific conditions. Piervittori et al. (1996) found that the distribution of $\mathrm{C}_{25}, \mathrm{C}_{27}, \mathrm{C}_{29}$, and $\mathrm{C}_{31} n$-alkanes in the lichen Xanthoria parietina varied significantly between two different Piedmont valleys in Italy and within the valleys with altitude, reflecting a combined influence of elevation, water availability, radiation, and temperature. For plaggen ecosystems, Kirkels et al. (2013) also observed significant variability in the reported ratios of the dominant $n$-alkanes with chain lengths $\mathrm{C}_{27}, \mathrm{C}_{29}, \mathrm{C}_{31}$, and $\mathrm{C}_{33}$ that is most likely attributable to the causes examined here. However, in spite of this they found meaningful clustering of the three different plant groups (grasses, shrubs, and trees), indicating that the variability did not obliterate the power of distinction (Kirkels et al., 2013). In a larger study based on 2093 observations from 86 sources of plant material, Bush and McInerney (2013) concluded that the general observation that $C_{27}$ and $\mathrm{C}_{29} n$-alkanes are dominant markers for woody vegetation and $\mathrm{C}_{31}$ for graminoids does not rigorously hold true. At the same time, $\mathrm{C}_{23}$ and $\mathrm{C}_{25} n$-alkanes do seem to be robust indicators of Sphagnum (Bush and McInerney, 2013) as observed by Baas et al. (2000) and Pancost et al. (2002). Bush and McInery (2013) indicated that the lack of rigor of the mentioned proxies is likely caused by environmental conditions as indicated by a shift in patterns across African savannah and rain forest environments.

The distinction between African savannah and rain forest environments in general and $C_{3}$ versus $C_{4}$ vegetation in particular have been the subject of more detailed research.
Vogts et al. (2009) studied the leaves and sometimes whole plants of 24 African rain forest and 45 savannah species. They found that as a result of environmental influence, including temperature and aridity, the chain length distributions of the $n$-alkanes and $n$-alcohols of some species shifted to different chain length predominance. The environmental influences overshadowed a taxonomic distinction at the order, family, or subfamily level (Vogts et al., 2009). Patterns in grasses were more consistent and thus less dependent on environmental factors (Vogts et al., 2009). As a result, in spite of the environmental variability observed, Vogts et al. (2009) found that by averaging lipid patterns within a given environment a clear distinction between rain forest and savannah plants can be made, with a dominance of $\mathrm{C}_{29} n$-alkane representative of the average rain forest plant signal and a dominance of $\mathrm{C}_{31} n$-alkane of the savannah plants and $\mathrm{C}_{4}$ savannah grasses. For the $n$-alcohols, $\mathrm{C}_{28}$ dominated on average for savannah plants, $\mathrm{C}_{30}$ for rain forest plants, and $\mathrm{C}_{32}$ for $\mathrm{C}_{4}$ savannah grasses (Vogts et al., 2009).

Rommerskirchen et al. (2006) observed a generally higher content of $\mathrm{C}_{31}$ and $\mathrm{C}_{33} n$-alkanes and therefore a higher ACL value in African $\mathrm{C}_{4}$ grasses with respect to $\mathrm{C}_{3}$ grasses from the same area as a result of the genetic adaptation of $\mathrm{C}_{4}$ grasses to warm, arid habitats. In addition, $n$-fatty acid patterns have also been shown to vary with $C_{3}$ and $C_{4}$ metabolism, with $\mathrm{C}_{3}$ crops having relatively large proportions of $\mathrm{C}_{24} n$-fatty acid in leaves, stems, and roots compared to $\mathrm{C}_{22}$ and $\mathrm{C}_{26} n$-fatty acids in $\mathrm{C}_{4}$ crops (Wiesenberg and Schwark, 2006).

\subsection{Conclusions and implications regarding source-related variability}

Herbin and Robins (1969) concluded that there is a basic genetic control on the composition of the wax components, including the $n$-alkanes, of plant leaves. However, variable factors associated with age and environment can be superimposed upon the specific pattern in some cases, while in others the genetically controlled pattern appears to be stable and unaffected by external influences (Herbin and Robins, 1969). Now, 48 years later, a much more extensive database has been accrued, albeit with a large emphasis on leaf wax lipids in general and $n$-alkanes in particular. Nevertheless, the results are still equivocal. On the one hand, there is ample evidence that genetically driven variability in leaf wax lipid composition in principle leads to chemotaxonomically meaningful clustering that can form the basis of the application of leaf wax lipids as molecular proxies. On the other hand, it is clear that both ontogeny and environmental factors can have a significant and sometimes dominant influence on lipid composition like chain length distribution. Matters are complicated by the fact that a lot of data with respect to the effects of environmental stress originate from studies in which plants were studied for a limited period of time (typically one growing season) and extreme conditions were ar- 
tificially imposed. In contrast, the lipid signal from soil or sediment archives as used in reconstructions typically represents a mixture of input of decades or longer from perennial plants in various life stages, induced diversity from the frequent changes of annual plants in managed ecosystems, and the average of natural fluctuations in stress conditions during that time period.

In general from what is known to date, the conclusion seems justified that because of genetic and environmental influences there are no unique compounds or "golden ratios" of different chain lengths of compounds that can always be linked to certain plants under all circumstances. However, there are many situations in which the influence of genetic and environmental effects are small enough that they do not prevent the use of plant lipids as molecular proxies. The currently available data do not allow for objective, quantitative rules to be formulated in this respect. From the plant wax components, the $n$-alkanes are the dominant class studied. In addition, research attention has focussed to a lesser extent on $n$-alcohols and $n$-fatty acids. The other wax components, such as isoprenoids and ester-bound lipids, have received hardly any research attention to date with respect to source-related variability in the context of their use as molecular proxies. Yet even for the $n$-alkane patterns in leaf waxes, only a tiny portion of the dominant plant species on the planet has been examined in detail for the effects of genetics and environment on their amounts and patterns. It is clear that much more research is needed in this respect.

Based on the current insights it seems prudent to explicitly take the possibility of genetically and environmentally driven variability in lipid patterns into account when considering the use of lipids as molecular proxies. This can be achieved, for instance, by considering plant species from the same climatic zone as that in which the reconstruction takes place and by mixing plant material from different life stages to obtain the average molecular fingerprint to look for.

\section{Input-pathway-related variability of molecular proxies}

\subsection{Definition}

Here we discuss differences in the amount and composition of molecules used as proxies, which is possible due to different input pathways of such molecules to the soil. A schematic representation of the different input routes of molecular proxies into the soil is provided in Fig. 1. The emphasis lies on potential effects for their use as molecular proxies. For a general description of the different molecular origins of organic matter in soil, the reader is referred to a dedicated review on this topic by Kögel-Knabner (2002).
Table 2. Average maximum rooting depth, biomass-depth distribution, and root / shoot ratios in different biomes (Canadell et al., 1996; Jackson et al., 1996).

\begin{tabular}{lrcr}
\hline Biome & $\begin{array}{r}\text { Average } \\
\text { maximum } \\
\text { rooting } \\
\text { depth [m] }\end{array}$ & $\begin{array}{c}\text { Average } \\
\text { percentage } \\
\text { of roots } \\
\text { in the } \\
\text { top } 0.3 \mathrm{~m}\end{array}$ & $\begin{array}{r}\text { Average } \\
\text { root / } \\
\text { shoot } \\
\text { ratio }\end{array}$ \\
\hline Boreal forest & $2.0 \pm 0.3$ & 83 & 0.32 \\
Cropland & $2.1 \pm 0.2$ & 70 & 0.10 \\
Desert & $9.5 \pm 2.4$ & 53 & 4.5 \\
Sclerophyllous shrubland and forest & $5.2 \pm 0.8$ & 67 & 1.2 \\
Temperate coniferous forest & $3.9 \pm 0.4$ & 52 & 0.18 \\
Temperate deciduous forest & $2.9 \pm 0.2$ & 65 & 0.23 \\
Temperate grassland & $2.6 \pm 0.2$ & 83 & 3.7 \\
Tropical deciduous forest & $3.7 \pm 0.5$ & 70 & 0.34 \\
Tropical evergreen forest & $7.3 \pm 2.8$ & 69 & 0.19 \\
Tropical grassland/savannah & $15.0 \pm 5.4$ & 57 & 0.70 \\
Tundra & $0.5 \pm 0.1$ & 93 & 6.6 \\
\hline
\end{tabular}

\subsection{Leaf versus root input}

Conservative estimates calculate roots to represent $33 \%$ of global annual net primary productivity (Jackson et al., 1997), whereas more recent studies highlight the fact that the contribution of root-derived organic matter in soils can account for $>70 \%$ of total plant-derived carbon (Rasse et al., 2005). As a result, roots form a considerable input of organic matter in soils and are proposed to improve carbon storage in soils (Kell, 2012). In addition, root input occurs to considerable depth in soils, ranging from an average depth of $0.5 \mathrm{~m}$ in tundra biomes to $15.0 \mathrm{~m}$ in tropical grassland/savannah (Canadell et al., 1996). Also in the temperate zone under certain circumstances, such as the presence of nutrient-rich fossil A horizons at depth, deep rooting can be very significant (Gocke et al., 2016). However, on average the majority of root biomass appears to be incorporated in the top $0.3 \mathrm{~m}$ of the soil in most biomes, i.e., in the topsoil (Jackson et al., 1996). The ratio of root/shoot biomass input is also very variable across biomes, ranging from an average of 0.10 in cropland to 4.5 in deserts (Jackson et al., 1996). Table 2 presents an overview of the average maximum rooting depth, root biomass input in the first $0.3 \mathrm{~m}$ of the soil, and the root/shoot biomass input for different biomes (see also Fig. 1).

If the molecules to be used as a proxy are present in both the leaves and roots of plants, the possibility of root input is also a factor that has to be considered depending on the purpose of the proxy. In the case of cutin and suberin monomers, root input does not cause interference as discerning root from leaf input is the specific purpose of this molecular proxy (Mendez-Millan et al., 2011). However, this may be different for the wax lipids, i.e., $n$-alkanes, $n$-alcohols, $n$-fatty acids, and isoprenoids, that have been found to occur in the leaves and roots of species at varying concentrations (Jansen et al., 2007; Huang et al., 2011). Particularly 


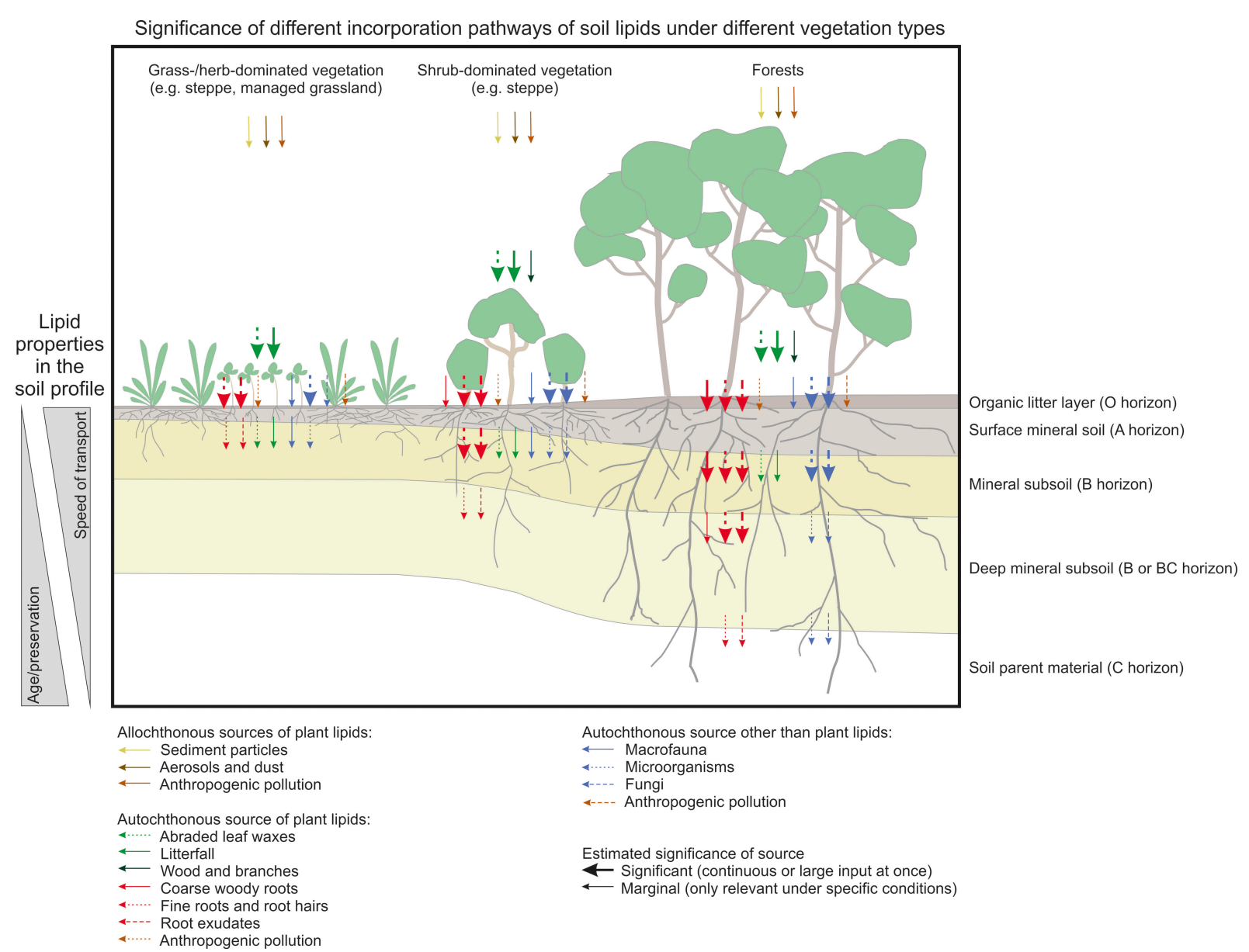

Figure 1. Conceptual overview of different incorporation pathways of lipids in soils originating from different biological sources and anthropogenic contamination. The different sources are indicated by distinct colors and lines of the arrows. The line thickness is an estimated significance of individual sources without providing a quantitative measure for different sources. Autochthonous sources are further distinguished by their significance in different soil depths or soil horizons. Further, the transport, age, and probability of preservation as general properties of lipids are given on the left side of the figure.

when such wax-derived lipids are applied as molecular proxies for vegetation cover in soil, root input can be an issue for two reasons: (i) roots may contain a different wax lipid composition than leaves qualitatively and quantitatively, thereby clouding the leaf signal (Jansen et al., 2006; Martelanc et al., 2007) and (ii) young root input at depth may disrupt the chronology of a reconstruction in time by overprinting the originally present signal (Lavrieux et al., 2012; Gocke et al., 2014).

The main discussion with respect to the influence of root input in wax-lipid-based environmental reconstructions from soils therefore revolves around assessing the relative importance of root versus aboveground biomass input. Since plant wax lipids reside on the outer parts of leaves and roots, relative surface area and bioproductivity are important. On a global scale, root surface area is almost always calculated to be higher than leaf surface area by more than an order of magnitude in grasslands (Jackson et al., 1997). However, in many cases the absolute amount of lipids present per mass unit of root material is an order of magnitude or more lower than on leaf material (Marseille et al., 1999; Zech et al., 2011). In addition, with respect to the degree to which wax lipid chain length patterns vary between the leaves and roots of plant species, there appears to be quite some variability. In general, the observed differences between roots and leaves of the same species are reported to be of the same order of magnitude as the differences between leaves of different species (e.g., Jansen et al., 2006; Kirkels et al., 2013; Gocke et al., 2014).

The concurrent influence of such various quantitative and qualitative factors makes the impact of root input a complex issue that is still the subject of scientific debate (Wiesenberg and Gocke, 2013). Given that different factors will have a highly variable influence in different situations, no general conclusion can be drawn. In some situations, the influence of roots as an input pathway of extractable lipids to be used as 
a molecular proxy may be limited (Quenea et al., 2006). In others, root input may be dominant (Van Mourik and Jansen, 2013). In addition, the relative degree of influence may vary greatly with depth, leading to the concurrent presence of leaflipid-dominated and root-lipid-dominated zones at different depths in the same profile (Angst et al., 2016).

\subsection{Microbial input}

In general, microbial biomass can be a significant source of soil organic matter, with up to $40 \%$ transformed to nonliving soil organic matter, but it is turned over much faster than plant residues (Miltner et al., 2012). Focusing specifically on lipids, isotopic studies show that $90 \%$ of fatty acids of microbial origin are turned over rapidly after cell death, whereas the majority of biomass-derived residual bulk $\mathrm{C}$ was stabilized in the nonliving soil organic matter pool (Kindler et al., 2009). In spite of the potentially shorter residence time, concurrent faster production makes microorganism-derived molecules a factor to consider when applying molecular proxies in soils, except when such proxies are used to study microbial input.

For wax lipids, $n$-alkanes, $n$-alcohols, and $n$-fatty acids with longer chain lengths $\left(>\mathrm{C}_{20}\right)$ and a distinct odd-overeven ( $n$-alkanes) or even-over-odd ( $n$-alcohols and $n$-fatty acids) chain length predominance are generally considered to be higher plant derived, whereas shorter chain length homologues are considered to be predominantly of microbial origin (Eglinton et al., 1962a; Dinel et al., 1990). Moreover, with the exception of an abundance of $\mathrm{C}_{16}$ and $\mathrm{C}_{18} n$ alcohol and $n$-fatty acid, such microbial lipids are described to lack a specific chain length predominance (Stevenson, 1994; Lichtfouse et al., 1995). However, several researchers challenge the observation that higher chain length lipids in soils are exclusively of higher plant origin. Microorganisms have been shown capable of synthesizing higher chain length straight-chain lipids, albeit usually to a limited extent (Ladygina et al., 2006; Nguyen Tu et al., 2011). Jambu et al. (1978) indicated that while chain lengths $>C_{20}$ in soils are predominantly plant derived, particularly in acidic soils, fungi may contribute such lipids as well. Furthermore, Marseille et al. (1999) observed an abundance of $C_{25}$ and $C_{27}$ $n$-alkanes that they also attribute to in situ production by fungi. This was confirmed for an agricultural soil by Quenea et al. (2006), who observed old-forest- and fungi-derived odd long-chain alkanes based on compound-specific isotope analysis and lipid distribution patterns. Possible pathways of in situ genesis of $n$-alkanes in soils are the reduction of $n$ alkenes and $n$-alcohols, the decarboxylation of bacterial $n$ fatty acids, and the degradation of biopolymers containing aliphatic side chains (Lichtfouse et al., 1998a). Nevertheless, based on the large number of studies in which typical higherplant-derived patterns of lipids are reported and used in soils (Table 1), including indicative ACL and CPI values, microbial input of longer chain length straight-chain lipids gener- ally does not seem to be a major factor compared to directplant-derived input in the topsoil (Jansen and Nierop, 2009; Bai et al., 2009). In contrast, for steroids and triterpenoids such as camposterol, stigmasterol, and lupeol, microbial input in soils can be considerable (Naafs et al., 2004a). As another example, arbuscular mycorrhizal fungi-derived $\beta$ sitosterol is by far the most abundant sterol identified in soils (Grandmougin-Ferjani et al., 1999).

With respect to cutin and suberin monomers, in situ genesis in soils through the microbial transformation of other precursor molecules can be an issue. For instance, the oxidation of free fatty acids could be a source of $\omega$-hydroxy fatty acids, whereas the microbial $\beta$-oxidation of unsaturated fatty acids and/or mid-chain hydroxy fatty acids may be a source of $\alpha$ and $\omega$-alkanediotic acids, thus clouding the cutin or suberin signal (Naafs et al., 2004b).

\subsection{Airborne input}

In addition to the in situ production and incorporation of soil lipids, airborne input must be considered. The distance of the airborne transport of larger constituents such as leaves can be expected to be limited. However, smaller physical forms containing lipids, such as aerosols and dust particles, can travel substantial distances (Conte and Weber, 2002), thus causing the input of alien molecules that may influence the local signal. This is of special importance when airborne sediments with a low content of organic matter are investigated, as in these environments low inputs of foreign organic matter can significantly influence the molecular proxies. Liu et al. (2007) showed that the $\delta^{13} \mathrm{C}$ signature of sediment organic carbon in loess deposits on the western Chinese Loess Plateau corresponds to that of dust sources instead of the local vegetation. In a study of marine sediment cores along the southwestern African continental margin, Rommerskirchen et al. (2003) revealed that the aerosol-derived input of higher chain length $n$-alkanes and $n$-alcohols provides a significant signal, the $\delta^{13} \mathrm{C}$ signal of which corresponded well with continental $\mathrm{C}_{3}$ and $\mathrm{C}_{4}$ plant distribution and fossil pollen input when prevailing wind patterns were taken into account. However, in this case, in contrast to vegetated soils, there was no in situ input from higher plant vegetation.

Aerosol studies above plant canopies revealed a certain relationship of the plant wax composition of the present plants, but significant differences from the biomass were observed for $n$-alkanols and $n$-alkanes (Conte et al., 2003). While the wax molecular composition was not directly linked between biomass and aerosol, the compound-specific isotope composition $\left(\delta^{13} \mathrm{C}\right)$ revealed a closer link to both. For Bermuda aerosols it could be shown that the aerosol compoundspecific isotope composition of $n$-alcohols and $n$-fatty acids reflects the plant wax compound-specific isotope composition and the course of the bioproductivity during the different seasons of the years (Conte and Weber, 2002). 
In a study of $\mathrm{PM}_{10}$ aerosols collected during a winter season in Baoij, China, Xie et al. (2009) found concentrations of $\mathrm{C}_{21}-\mathrm{C}_{33} n$-alkanes in the $10-600 \mathrm{ng} \mathrm{m}^{-3}$ range as a result of intensive coal burning in the region. In a 2-year study of $\mathrm{PM}_{10}$ and $\mathrm{PM}_{2.5}$ aerosols in urban sites in Nanjing, Wang et al. (2006) observed $\mathrm{C}_{21}-\mathrm{C}_{33} n$-alkanes present in the 10 $100 \mathrm{ng} \mathrm{m}^{-3}$ range. Concentrations of $\mathrm{C}_{21}-\mathrm{C}_{35} n$-alkanes in $\mathrm{PM}_{10}$ aerosols in urban sites in Beijing sampled in all seasons were even lower (Zhou et al., 2009). In this study $n$-fatty acids and hopanes were also considered, but were found in small concentrations that together with the $n$-alkanes constituted ca. $3 \%$ of the total organic matter in the aerosols (Zhou et al., 2009). In all studies, the straight-chain lipid patterns lacked the odd-over-even chain length predominance typical of higher plants (Wang et al., 2006; Xie et al., 2009; Zhou et al., 2009). Nevertheless, in a large survey a clear odd-overeven chain length predominance was found in spite of such potentially intense aerosol-derived input (Rao et al., 2011). This indicates that even in areas under large aerosol deposition, as in the case of the intensive anthropogenic pollution associated with fossil fuel burning, the effect of aerosol deposition on $n$-alkane patterns in the soil is limited as a result of the large in situ input via the roots and leaves of the local vegetation.

\subsection{Conclusions and implications regarding input-pathway-related variability}

The diversity of input pathways offers both opportunities and limitations for the use of molecular proxies. Opportunities arise when different sources can be elucidated using molecular proxies. Examples are the differences in the molecular composition of leaf and root waxes as used to differentiate between their respective influences or when aerosol-associated lipids are used for the source apportionment of terrestrial plant input in terrestrial or marine sediments. This can help budget the organic matter input of different sources and thus improve (paleo)environmental interpretations and reconstructions. Limitations are imposed when input through multiple pathways clouds the linkage of a (set of) molecule(s) to a certain source for which it is to serve as a proxy, for instance when linking a suite of straightchain lipids to a particular group of plants at a certain site. When looking at the application of molecular proxies in soils, the assessment of the influence of root-derived input is a particular challenge that is not always acknowledged. The significance of root-derived organic matter in soils and terrestrial sediments has been neglected for decades and has only recently been highlighted (Rasse et al., 2005; Rumpel and Kögel-Knabner, 2011). More research attention is needed to pinpoint how large the possible interferences are and what the potential can be to compensate for them, e.g., through modeling approaches. For instance, the VERHIB model was designed to unravel the mixed $n$-alkane, $n$-alcohol, and/or $n$ fatty acid signal observed in soils into the most likely com- bination of plant groups responsible for the original lipid input by treating leaves and roots explicitly as separate entities (Jansen et al., 2010). This might form a starting point to disentangle leaf- and root-derived lipid input.

Although aerosol studies so far have provided the useful information that plant wax components are transported via aerosols to remote places, other factors like degradation during transport and the integration of regional vegetation patterns may hamper direct source-to-sink relationships of airborne molecular markers. Nevertheless, the overall impact of aerosol-borne molecules on molecular-proxy-based reconstructions seems to be limited whenever the total abundance in the soil is high.

\section{Transformations and turnover in soil}

Transformations and the turnover of soil organic matter are an important study area in their own right (Kögel-Knabner, 2002; Von Lützow et al., 2008). Important in the context of the application of molecular proxies is the recent paradigm shift to the attribution of external factors as drivers of SOM turnover rates as opposed to inherent recalcitrance related to molecular structure (Schmidt et al., 2011; Lehmann and Kleber, 2015). Coupled to this are indications that the microbial recycling of organic matter upon entering the soil decouples the molecules from their biological sources (Miltner et al., 2012; Gleixner, 2013). Here, we focus on the effects of transformation and the differences in the degradation of molecules in soils for their use as molecular proxies. This includes transformations during the stages of senescence or litter, and it covers attempts to estimate the successive degradation processes of organic matter occurring after burial until the stages of long-term preservation (see also Fig. 1). Transformation processes can also include processes that affect the detectability of a molecule used as a proxy, for instance a transformation from the extractable to the non-extractable lipid fraction as a result of chemical alterations or interactions with the mineral phase (e.g., Almendros et al., 2001). A special case is the influence of fire on SOM, including molecular proxies, as reviewed by González-Pérez et al. (2004).

All of the attempts dealing with the incorporation and preservation of organic matter involve different assumptions and entail different problems in terms of uncertainties. Thus, in the dependency of the environmental conditions, assumptions that are relevant for the incorporation and burial of organic matter play a major role, as should the different aspects of degradation and preservation. However, much uncertainty currently exists regarding the influences of individual environmental and genetic factors in degradation and preservation. Therefore, the following paragraphs only provide the first insights into tackling these issues, which need further attention in future research projects.

Molecular transformations and variations thereof in molecular proxies mostly complicate the application of 
molecular proxies. However, in some instances they may also offer opportunities. For instance, $n$-alkanes can be degraded to $n$-methyl ketones through $\beta$-oxidation (Chaffee et al., 1986; Amblès et al., 1993), which can be used to assess and trace $n$-alkane degradation in soils (Jansen and Nierop, 2009). Similarly, the presence of certain seco acids formed through the A-ring opening of 3-oxytriterpenoids under anaerobic conditions may be used as a proxy for the occurrence of such anaerobic episodes (Jaffe et al., 1996), e.g., under stagnant water conditions.

\subsection{Differences related to incorporation pathway}

The incorporation pathway (Fig. 1) may influence the subsequent turnover of molecular proxies. This includes (differences in) degradation during senescence and/or litter degradation stages, e.g., due to different input shapes (like root versus leaf), that offer a different degree of physical protection. It also includes alterations induced by fire prior to or upon incorporation of organic matter into the soil.

In a study of Ginkgo biloba leaf wax lipids during the senescence and litter stages, Nguyen Tu et al. (2003) found limited degradation that did not affect the dominant chain lengths of alkyl molecular proxies. When comparing different classes of wax lipids they found the $n$-alkanes to be the most resistant to degradation, followed by the $n$-fatty acids and then the $n$-alcohols (Nguyen Tu et al., 2003). More generally in a study of grassland and forest soils, Otto and Simpson (2005) determined that the characteristic patterns of wax lipids and isoprenoids were preserved throughout the stages between fresh plant material and soil organic matter. They also determined preferential enrichment of suberin with respect to cutin monomers, in particular in one of the grassland soils (Simpson et al., 2008). This indicated, for example, that the former is embedded in woody tissue, while the latter is exposed on leaf surfaces (Simpson et al., 2008) (see also Sect. 4.3.3).

When looking at bulk organic matter in soils, Rasse et al. (2005) estimated that the main residence time of rootderived organic matter is on average 2.4 times that of shootderived organic matter. When comparing cutin and suberin monomers, Andreetta et al. (2013) described the selective preservation of leaf-derived monomers in the more acidic and dryer soil, while in the more fertile soil root-derived monomers were preferentially preserved. They attributed the former to inhibited microbial degradation due to drought and acidity and the latter to protection within aggregates. In another study, small differences in the degradation of the same $n$-alkanes derived from different plants were found, with a slower degradation of $n$-alkanes derived from more woody roots (Nierop and Jansen, 2009), although lipids were generally well preserved. Killops and Frewin (1994) reported that the persistence of plant cuticles protected their composite isoprenoids from degradation in mangrove sediments. Similar preservation in soils is also perceivable.
More in general, Mambelli et al. (2011) observed root litter, including biomarkers, to be selectively preserved with respect to needle litter, which was confirmed by MendezMillan et al. (2010a, b) for maize and wheat roots versus shoots. Using isotopic signatures, Mendez-Millan et al. (2011) were able to quantify and subsequently compensate for such differences in turnover rate. This further emphasizes the significance of root-derived organic matter for turnover determinations as discussed by Wiesenberg et al. (2004). In other words, the relative abundance of roots and the uncertainties in terms of root-related overprint in the rhizosphere and rhizosphere extension entail large uncertainties and strong differences between different plant species and environmental settings, especially at a molecular level. Further research is required to enable extrapolations to or across ecosystem scales.

With respect to the effects of fire, the burning of litter or biomass can release additional extractable lipids (GonzálezPérez et al., 2004). In addition, fire has been reported to alter the chain length distribution of $n$-alkanes and $n$-fatty acids, shifting it towards shorter chain lengths (González-Pérez et al., 2004; Wiesenberg et al., 2009; Knicker et al., 2013). The composition of terpenoids can also be influenced, resulting in the preferential degradation of those with the lowest thermal stability (González-Pérez et al., 2004). All such processes potentially adversely affect the application of molecular proxies to an extent that depends on the frequency and intensity of fires. At the same time, fire events may also offer opportunities. For instance, the thermal alteration of animal fats in fireplaces may produce specific $n$-alkane/ $n$-alkene doublets preserved in the soil, the presence of which can be used to reconstruct human fire usage in an archaeological context (Lejay et al., 2016).

\subsection{Differences between different soil compartments}

When soils are used as archives of molecular proxies, mostly bulk samples are used and replication per horizon or stratigraphic layer is often limited or absent. However, several studies indicate that the preservation of molecules used as proxies can differ between different soil compartments (Flessa et al., 2008; Clemente et al., 2011; Griepentrog et al., 2014). Depending on the research question, this may pose a problem; for instance, it might obscure chronology when molecules are used as proxies to reconstruct changes over time.

Lichtfouse et al. (1998b) showed that straight-chain lipids can become encapsulated in larger organic macromolecules, thus being protected against degradation. In addition, physical protection in (the micropores of) aggregates and/or through association with clay minerals has been identified as an important pathway for the stabilization of soil organic matter in general, including molecules used as molecular proxies (Tonneijck et al., 2010). Using bulk and compoundspecific $\delta^{13} \mathrm{C}$ analysis, Cayet and Lichtfouse (2001) showed 
that plant-derived $n$-alkanes in a soil under maize cultivation varied in average age per particle size fraction, with the $C_{31}$ $n$-alkane from the $200-2000 \mu \mathrm{m}$ fraction being significantly younger than that from the 50-200 and 0-50 $\mu \mathrm{m}$ fractions. A general trend of preferential preservation in smaller size fractions, in particular the clay fraction, is also reported in other studies. For instance, Quenea et al. (2004) and Flessa et al. (2008) observed longer turnover rates of SOM in smaller size fractions. Clemente et al. (2011) studied the preservation of long-chain aliphatic compounds in three soils with similar clay mineralogy but different carbon contents and standing vegetation. Regardless of these differences, they too found the aliphatic compounds to be preferentially preserved in the silt and clay fractions and again linked this to strong interactions with the present clay minerals. In a recent study, Griepentrog et al. $(2015,2016)$ confirmed the higher residence time of organic matter in small size density fractions when compared to macroaggregates as a result of interaction with the mineral phase. This implies an improved preservation of organic matter associated with higher density and thus mineral association when compared to organic matter associated with lower density. However, physical fractionation techniques such as particle and density fractionation have the potential of creating analytical artifacts, especially when molecular proxies are investigated. In addition, occlusion or strong adsorption in the smallest mineral fractions might hamper the extraction and analysis of the proxy in question.

Furthermore, the effects of size or density fractions of the soil on the preservation of organic matter, including molecular proxies, are not uniform. For instance, Höfle et al. (2013) found size- and density-fraction-related organic matter stabilization to be much less pronounced in the active upper layer than in the deeper soil horizons. This points to the selective preservation of organic matter in the deeper soil because of more extensive aggregation and organo-mineral association. In a study of volcanic ash soils, Stewart et al. (2011) did not find differences in the preservation of bulk SOM in general or lipids in particular between different size fractions. They attributed this lack of differentiation to the presence of a large proportion of SOM that was not associated with mineral components as these were already saturated with previously incorporated soil organic matter (Stewart et al., 2011).

In general a combination of physical protection and sorptive preservation seems to be responsible for the observed differences (or lack thereof) in the preservation of organic molecules in soils between different size or density fractions. This is corroborated amongst others by a study by Guggenberger et al. (1995) in which they observed differences in the preservation of SOM derived from tropical pastures compared to the preceding native savannah vegetation. They attributed this effect to a difference in interactions with the mineral phase, leading to the physical protection of SOM and the molecular proxies contained therein. Similarly, differences in the turnover rates of approximately 1 order of magnitude between forest- and grass-derived molecules after land use change have been observed as a result of saturation of the adsorption sites on the mineral phase (Hamer et al., 2012).

In addition to heterogeneity in the effects of interactions with the mineral phase on the preservation of molecular proxies, analytical artifacts cannot be completely excluded when physical and chemical fractionation techniques are applied to separate particle size or density fractions. To date, systematic investigations addressing these issues are lacking, which hampers the drawing of general conclusions with respect to processes that are relevant, e.g., under different climates and for different soil mineralogical composition.

\subsection{Selective preservation within or between classes of molecules}

The turnover rates of molecular proxies not only vary between different compartments, but may also vary within the same compartment between and even within different (classes of) molecules (Dinel et al., 1990; Bull et al., 2000; Amelung et al., 2008). For instance, Feng and Simpson (2007) found preferential enrichment of straight-chain lipids and cutin and suberin monomers with increasing depth with respect to bulk SOM. In contrast, in a study of grain-maize and silage-maize cropped soils, Wiesenberg et al. (2004) found turnover times in the sequence bulk SOM $>n$-alkanes $>n$-fatty acids, with rate differences that varied substantially between the two cultivations. The differences could be related to the different biomass input on the one hand and large amount of lignite dust and the low biomass input on the other hand, thus hampering degradation at this site. The faster turnover of $n$-fatty acids than $n$ alkanes was also confirmed by Wiesenberg et al. (2008a) and Griepentrog et al. $(2015,2016)$. This may also offer opportunities to apply such differences between molecular classes and their response to external factors to trace transformations and input of organic matter in soils (Feng and Simpson, 2007).

An important issue with respect to the application of straight-chain lipids as molecular proxies is also the preferential degradation of certain chain lengths within a certain class of molecules, as molecular ratios of various (higher) chain lengths are often used as proxies for certain vegetation types (see Sect. 2). This issue is addressed in the following sections.

\subsubsection{Straight-chain lipids}

Moucawi et al. (1981a) reported decreasing degradation rates with larger chain lengths for $n$-alkanes in soils, which was confirmed by Lichtfouse et al. (1998a), who determined a higher resistance of long straight-chain lipids in soil compared to their shorter-chain counterparts. However, such preferential degradation was found in agricultural and acidic 
soils in the absence of $\mathrm{Fe}(\mathrm{OH})_{3}$ (Moucawi et al., 1981a; Lichtfouse et al., 1998a). Similar results were found for other lipid classes as well (Moucawi et al., 1981b). More recently, several authors have also indicated that such preferential degradation can occur in other soils (Jansen and Nierop, 2009; Cui et al., 2010). However, the extent of the effect calls into question the suitability of the compounds as molecular proxies. For instance, Jansen and Nierop (2009) found the overall effect of preferential degradation on higher-plantderived $n$-alkane patterns in soils to be small and not of influence for their use as a vegetation proxy. Similarly, Lei et al. $(2010 a, b)$ determined that in spite of strong evidence of microbial degradation, the relative abundance of long-chain $n$-alkanes could still be used to distinguish coniferous from broadleaf tree input in soils.

Within the group of straight-chain lipids, the overall degradation rates of subclasses have been found to vary depending on soil physicochemical properties. For instance, $n$-alkanes have been reported to be better preserved in alkaline soils, whereas $n$-fatty acids accumulate in more acidic soils (Simpson et al., 2008).

\subsubsection{Isoprenoids}

Isoprenoids are reported to have varying turnover rates under both oxic and anoxic conditions in soils (Jaffe et al., 1996; Amelung et al., 2008). Generally, sterols, diterpenes, and pentacyclic, triterpenes are reported to be turned over rapidly compared to straight-chain lipids in grassland and forest soils, hindering their application as molecular proxies for their sources (Bull et al., 2000; Naafs et al., 2004b; Jansen et al., 2007). However, Otto and Simpson (2005) observed the exact opposite trend, indicating a strong environmental control on the relative transformation rate of different classes of components. In an incubation study of derived triterpenols, Koch et al. (2005) highlighted marked differences between the degradation rates of individual triterpenols, leading to a sharp relative increase in the proportion of taraxerol with respect to the other triterpenols.

In addition, $\Delta^{5}$ sterols are transferred both aerobically and anaerobically to $5 \alpha$ - and $5 \beta$-stanols (De Leeuw and Baas, 1986), which are reported to persist much longer in soils than their precursors (Bull et al., 2000). Simpson et al. (2008) suggest using the ratio of precursor sterols to their stanol and stanone degradation products as a measure of their degree of degradation.

\subsubsection{Cutin and suberin monomers}

Bull et al. (2000) observed different degradation rates for different components within the classes of free and ester-bound lipids, depending on soil chemical and physical composition. However, Otto and Simpson (2006) found the degradation of cutin and suberin to take place without preference for specific constituents. In general, Quenea et al. (2004) described cutin and suberin to be more resistant to degradation than free lipids residing in the same particle size fraction.

In a study of hydrolysable lipids using compound-specific ${ }^{13} \mathrm{C}$ analysis, Feng et al. (2010) described the mean turnover times for cutin- and suberin-derived ester-bound lipids of 3234 years. While slower than for bulk soil organic matter in this system, it was much shorter than anticipated, leading them to conclude that a large portion of cutin- and suberinderived compounds reside in the non-hydrolysable fraction (Feng et al., 2010).

As mentioned earlier (Sect. 4.1), Simpson et al. (2008) observed the preferential enrichment of suberin monomers with respect to cutin monomers, which was confirmed by Mendez-Millan et al. (2010b). In addition to the physical location of suberin versus cutin as a potential cause, Simpson et al. (2008) suggested a higher resistance of suberin to degradation than cutin owing to a larger content of phenolic units in the former. Mendez-Millan et al. (2010b) argued that microbial degradation, potentially influenced by the access to degradation sites, is another factor influencing the slower turnover of suberin versus cutin monomers. Regardless of the mechanism, the general difference in root versus aboveground biomass-derived suberin and cutin monomers and their individual turnover would clearly influence the application of the cutin/suberin monomer ratio as a proxy for leaf versus root input.

\subsection{Conclusions and implications regarding differences in transformations and turnover of molecular proxies in soils}

Although available data are limited, it is clear that the degradation of organic matter at a molecular level in terrestrial archives such as soils, paleosols, and sediments can significantly influence the applicability of molecular proxies. As a result it seems useful to explore the possibility of a correction to improve the determination of paleovegetation, vegetation shifts, and other paleoenvironmental information like paleotemperature and $\mathrm{pH}$. The number of published approaches to compensate for the influence of degradation on paleoenvironmental reconstructions is still small. Zech et al. (2009a) provided a simple two-end-member model approach to improve paleovegetation reconstruction based on the molecular ratios of different long-chain $n$-alkanes $\left(\mathrm{C}_{27}-\mathrm{C}_{33}\right)$. Assuming that forest vegetation is dominated by $n-\mathrm{C}_{27}$ alkane and grass vegetation by $n-\mathrm{C}_{31}$ and $n-\mathrm{C}_{33}$ alkanes, high relative contributions of the respective homologues of the assumed source vegetation are used as end-members. At the same time, the source vegetation is typically characterized by high odd-over-even predominance of long-chain $n$-alkanes. On the other hand, soils reveal a low odd-over-even predominance and the abovementioned molecular ratios with smaller differences between the different vegetation types. In theory, the degradation continuum from the plant leaves to the soils of the respective vegetation type thus enables the identifica- 
tion of the degradation intensity of an unknown sample if the sample is mainly influenced by a single vegetation. If the unknown sample does not plot on the degradation continuum but between the different lines of different vegetation types, the relative contribution of grass- versus tree-derived vegetation might be estimated and also corrected for the vegetation.

A slightly different approach was established by Buggle et al. (2010) who also used long-chain $n$-alkane ratios and the odd-over-even predominance of alkanes for their correction. While Zech et al. (2009a) used correlations and then graphically based reconstructions, Buggle et al. (2010) used a calculation-based approach. The degradation in the continuum from recent soils is taken as an analogy and the slope of the regression line is multiplied with the odd-over-even predominance and the addition of the intercept of a longchain $n$-alkane ratio in the cross plot of the ratio with the odd-over-even predominance. By moving the regression line to an ancient sample set, the end of the regression line yields the former topsoil value of the molecular ratio and odd-overeven predominance. Variation in the corrected long-chain $n$ alkane ratio enables the assessment of fluctuations in paleovegetation.

Both of the mentioned approaches rely on the general differentiation of grass versus forest vegetation based on longchain $n$-alkane composition. As mentioned above, such a clear distinction of vegetation types exclusively based on compounds deriving from one compound fraction, such as $n$ alkanes, might be hampered by various factors such as variability within and between plant species, thus leading to similar composition of, for example, $n$-alkanes from coniferous trees and grass plants (Maffei, 1996b; Maffei et al., 2004). Thus, such simple approaches might be appropriate only in very well-defined settings in which independent records such as pollen data confirm the composition of specific plant assemblages determined by molecular proxies.

The expansion of approaches like the ones mentioned here to a broader range of molecular proxies is required to receive a more complete picture and to acknowledge the different turnover and degradation of different substance classes. However, the availability of datasets on plant and soil chemical composition for substance classes other than the $n$-alkanes is quite limited, hindering such expanding approaches. Thus, further surveys are required for molecular proxies other than $n$-alkanes for a high diversity of plants and soils from different climates. Afterwards, combined studies of more than one substance class will enable improved paleoenvironmental reconstructions, whereas cross-checking with other nonmolecular proxies, e.g., fossil pollen data, might be essential, especially if the paleorecord is targeted. The extrapolation of such approaches to different environmental and climatic settings might also be limited as the effects of temperature, moisture, oxygen availability, and other factors influence the degradation of organic matter as discussed above. Consequently, proper modeling approaches are required to assess not only palaeoenvironmental changes, but also to acknowledge and identify the degradation of organic matter at a molecular scale.

\section{General conclusions}

In this review we considered the three most important constraining factors for the application of molecular proxies in soil science: (i) variability in the molecular composition of plant-derived organic matter as a result of genetic or life stage variations or external environmental factors; (ii) variability in (the relative contribution of) input pathways into the soil; and (iii) the transformation and/or (selective) degradation of (some of) the molecules once present in the soil. From the various studies within and outside of soil science over the last decades, the following general picture emerges. All constraining factors considered can have a significant influence on the applicability of molecular proxies in soil science. The degree of influence of the constraining factors strongly depends on the type of molecular proxy and the environmental context in which it is applied. In addition, the research question to be addressed through the application of the molecular proxy has a strong influence. A factor that poses a constraining factor in one study might offer an opportunity in another. For instance, the fire-induced alteration of biomass may release lipids to the soil that potentially confound their chemotaxonomic application, but may offer opportunities for the reconstruction of the occurrence of human-induced fire in an archaeological context. Recently, the first modeling approaches to potentially compensate for some of the constraining factors, specifically variability in input pathways and the degradation of molecular proxies once in the soil, have started to emerge. Based on the above discussion, we strongly recommend that the potential constraining factors always be explicitly considered whenever studies are planned in which molecular proxies in soils play a role. This review may serve as a starting point for gathering the necessary information to decide which constraining factors may play a role and how they can best be addressed. At the same time, it became clear from the available literature that much information about the mentioned constraining factors is still lacking. In particular for molecular classes other than $n$-alkanes, systematic information is often very scarce. We therefore strongly appeal to the soil scientific community to address this knowledge gap. Our review may also serve as a starting point in this respect with future applicability in soil science and in paleopedology.

Data availability. No data sets were used in this article.

Competing interests. The authors declare that they have no conflict of interest. 
Acknowledgements. We would like to thank the Executive Editors of SOIL for inviting us to write this review paper. In addition, we are indebted to the anonymous reviewers and other colleagues who provided comments that helped shape and improve our paper.

Edited by: Raúl Zornoza

Reviewed by: three anonymous referees

\section{References}

Ainsworth, E. A. and Long, S. P.: What have we learned from 15 years of free-air $\mathrm{CO}_{2}$ enrichment (FACE)? A meta-analytic review of the responses of photosynthesis, canopy, New Phytol., $165,351-371,2005$.

Almendros, G., Tinoco, P., González-Vila, F. J., Lüdemann, H. D., Sanz, J., and Velasco, F.: ${ }^{13}$ C NMR of forest soil lipids, Soil Sci., 166, 186-196, 2001.

Amblès, A., Jambu, P., Jacquesy, J. C., Parlanti, E., and Secouet, B.: Changes in the ketone portion of lipidic components during the decomposition of plant debris in a hydromorphic forest Podzol, Soil Sci., 156, 49-56, 1993.

Amelung, W., Brodowski, S., Sandhage-Hofmann, A., and Bol, R.: Combining biomarker with stable isotope analyses for assessing the transformation and turnover of soil organic matter, Adv. Agron., 100, 155-250, 2008.

Andersson, R. A., Kuhry, P., Meyers, P., Zebuhr, Y., Crill, P., and Morth, M.: Impacts of paleohydrological changes on $n$-alkane biomarker compositions of a Holocene peat sequence in the eastern European Russian Arctic, Org. Geochem., 42, 1065-1075, 2011.

Andreetta, A., Dignac, M., and Carnicelli, S.: Biological and physico-chemical processes influence cutin and suberin biomarker distribution in two Mediterranean forest soil profiles, Biogeochemistry, 112, 41-58, 2013.

Angst, G., John, S., Mueller, C. W., Kögel-Knabner, I., and Rethemeyer, J.: Tracing the sources and spatial distribution of organic carbon in subsoils using a multi-biomarker approach, Sci. Rep., 6, 29478, https://doi.org/10.1038/srep29478, 2016.

Avato, P., Bianchi, G., and Mariani, G.: Epicuticular waxes of Sorghum and some compositional changes with plant age, Phytochemistry, 23, 2843-2846, 1984.

Baas, M., Pancost, R., Van Geel, B., and Damste, J. S. S.: A comparative study of lipids in Sphagnum species, Org. Geochem., 31, 535-541, 2000.

Bai, Y., Fang, X. M., Wang, Y. L., Kenig, F., Miao, Y. F., and Wang, Y. X.: Distribution of aliphatic ketones in Chinese soils: Potential environmental implications, Org. Geochem., 37, 860-869, 2006.

Bai, Y., Fang, X., Nie, J., Wang, Y., and Wu, F.: A preliminary reconstruction of the paleoecological and paleoclimatic history of the Chinese Loess Plateau from the application of biomarkers, Palaeogeogr. Palaeocl., 271, 161-169, 2009.

Bai, Y., Fang, X., Gleixner, G., and Mügler, I.: Effect of precipitation regime on $\delta \mathrm{D}$ values of soil $n$-alkanes from elevation gradients - Implications for the study of paleo-elevation, Org. Geochem., 42, 838-845, 2011.

Baker, E. A. and Hunt, G. M.: Developmental changes in leaf epicuticular waxes in relation to foliar penetration, New Phytol., 88, 731-747, 1981.
Bakht, J., Bano, A., and Dominy, P.: The role of abscisic acid and low temperature in chickpea (Cicer arietinum) cold tolerance. II. Effects on plasma membrane structure and function, J. Exp. Bot., 57, 3707-3715, 2006.

Berke, M. A., Johnson, T. C., Werne, J. P., Grice, K., Schouten, S., and Sinninghe Damsté, J. S.: Molecular records of climate variability and vegetation response since the Late Pleistocene in the Lake Victoria basin, East Africa, Quaternary Sci. Rev., 55, 59-74, 2012.

Bettaieb, I., Bourgou, S., Wannes, W. A., Hamrouni, I., Limam, F., and Marzouk, B.: Essential oils, phenolics, and antioxidant activities of different parts of cumin (Cuminum cyminum L.), J. Agric. Food Chem., 58, 10410-10418, 2010.

Birk, J. J., Dippold, M., Wiesenberg, G. L. B., and Glaser, B.: Combined quantification of faecal sterols, stanols, stanones and bile acids in soils and terrestrial sediments by gas chromatographymass spectrometry, J. Chrom. A, 1242, 1-10, 2012.

Bol, R., Eriksen, J., Smith, P., Garnett, M. H., Coleman, K., and Christensen, B. T.: The natural abundance of ${ }^{13} \mathrm{C},{ }^{15} \mathrm{~N},{ }^{34} \mathrm{~S}$ and ${ }^{14} \mathrm{C}$ in archived (1923-2000) plant and soil samples from the Askov long-term experiments on animal manure and mineral fertilizer, Rapid Commun. Mass Spectrom., 19, 3216-3226, 2005.

Bondada, B. R., Oosterhuis, D. M., Murphy, J. B., and Kim, K. S.: Effect of water stress on the epicuticular wax composition and ultrastructure of cotton (Gossypium hirsutum L.) leaf, bract, and boll, Environ. Exp. Bot., 36, 61-69, 1996.

Brennan, C. W., Verhaak, R. G. W., McKenna, A., Campos, B., Noushmehr, H., Salama, S. R., Zheng, S., Chakravarty, D., Sanborn, J. Z., Berman, S. H., Beroukhim, R., Bernard, B., Wu, C., Genovese, G., Shmulevich, I., Barnholtz-Sloan, J., Zou, L., Vegesna, R., Shukla, S. A., Ciriello, G., Yung, W. K., Zhang, W., Sougnez, C., Mikkelsen, T., Aldape, K., Bigner, D. D., Van Meir, E. G., Prados, M., Sloan, A., Black, K. L., Eschbacher, J., Finocchiaro, G., Friedman, W., Andrews, D. W., Guha, A., Iacocca, M., O’Neill, B. P., Foltz, G., Myers, J., Weisenberger, D. J., Penny, R., Kucherlapati, R., Perou, C. M., Hayes, D. N., Gibbs, R., Marra, M., Mills, G. B., Lander, E., Spellman, P., Wilson, R., Sander, C., Weinstein, J., Meyerson, M., Gabriel, S., Laird, P. W., Haussler, D., Getz, G., Chin, L., and TCGA Res Network: The somatic genomic landscape of glioblastoma, Cell, 155, 462-477, 2013.

Buggle, B., Wiesenberg, G. L. B., and Glaser, B.: Is there a possibility to correct fossil $n$-alkane data for postsedimentary alteration effects?, Appl. Geochem., 25, 947-957, 2010.

Bull, I. D., Simpson, I. A., Dockrill, S. J., and Evershed, R. P.: Organic geochemical evidence for the origin of ancient anthropogenic soil deposits at Tofts Ness, Sanday, Orkney, Org. Geochem., 30, 535-556, 1999.

Bull, I. D., Nott, C. J., Van Bergen, P. F., Poulton, P. R., and Evershed, R. P.: Organic geochemical studies of soils from the Rothamsted Classical Experiments - VI. The occurrence and source of organic acids in an experimental grassland soil, Soil Biol. Biochem., 32, 1367-1376, 2000.

Bush, R. T. and McInerney, F. A.: Leaf wax $n$-alkane distributions in and across modern plants: Implications for paleoecology and chemotaxonomy, Geochim. Cosmochim. Ac., 117, 161-179, 2013. 
Canadell, J., Jackson, R. B., Ehleringer, J. R., Mooney, H. A., Sala, O. E., and Schulze, E. D.: Maximum rooting depth of vegetation types at the global scale, Oecologia, 108, 583-595, 1996.

Castañeda, I. S. and Schouten, S.: A review of molecular organic proxies for examining modern and ancient lacustrine environments, Quaternary Sci. Rev., 30, 2851-2891, 2011.

Cayet, C. and Lichtfouse, E.: $\delta^{13} \mathrm{C}$ of plant-derived $n$-alkanes in soil particle-size fractions, Org. Geochem., 32, 253-258, 2001.

Chaffee, A. L., Hoover, D. S., Johns, R. B., and Schweighardt, F. K.: Biological markers extractable from coal, in: Biological markers in the sedimentary record, edited by: Johns, R. B., Elsevier, Amsterdam, 311-345, 1986.

Clemente, J. S., Simpson, A. J., and Simpson, M. J.: Association of specific organic matter compounds in size fractions of soils under different environmental controls, Org. Geochem., 42, 11691180, 2011.

Clemente, Z., Castro, V. L. S. S., Moura, M. A. M., Jonsson, C. M. and Fraceto, L. F.: Toxicity assessment of $\mathrm{TiO}_{2}$ nanoparticles in zebrafish embryos under different exposure conditions, Aquat. Toxicol., 147, 129-139, 2014.

Concheri, G., Bertoldi, D., Polone, E., Otto, S., Larcher, R., and Squartini, A.: Chemical elemental distribution and soil DNA fingerprints provide the critical evidence in murder case investigation, Plos One, 6, e20222, https://doi.org/10.1371/journal.pone.0020222, 2011.

Conte, M. H. and Weber, J. C.: Plant biomarkers in aerosols record isotopic discrimination of terrestrial photosynthesis, Nature, 417 , 639-641, 2002.

Conte, M. H., Weber, J. C., Carlson, P. J., and Flanagan, L. B.: Molecular and carbon Isotopic composition of leaf wax in vegetation and aerosols in a northern prairie ecosystem, Oecologia, 135, 67-77, 2003.

Conte, P., Spaccini, R., Chiarella, M., and Piccolo, A.: Chemical properties of humic substances in soils of an Italian volcanic system, Geoderma, 117, 243-250, 2003.

Cowlishaw, M. G., Bickerstaffe, R., and Young, H.: Epicuticular wax of four species of Chionochloa, Phytochemistry, 22, 119124, 1983.

Cui, J., Huang, J., Meyers, P. A., Huang, X., Li, J., and Liu, W.: Variation in solvent-extractable lipids and $n$-alkane compoundspecific carbon isotopic compositions with depth in a Southern China karst area Soil, J. Earth Sci., 21, 382-391, 2010.

Curiale, J. A.: A review of the occurrences and causes of migrationcontamination in crude oil, Org. Geochem., 33, 1389-1400, 2002.

D’Anjou, R. M., Bradley, R. S., Balascio, N. L., and Finkelstein, D. B.: Climate impacts on human settlement and agricultural activities in northern Norway revealed through sediment biogeochemistry, P. Natl Acad. Sci. USA, 109, 20332-20337, https://doi.org/10.1073/pnas.1212730109, 2012.

De Jonge, C., Hopmans, E. C., Zell, C. I., Kim, J., Schouten, S., and Sinninghe Damsté, J. S.: Occurrence and abundance of 6-methyl branched glycerol dialkyl glycerol tetraethers in soils: Implications for palaeoclimate reconstruction, Geochim. Cosmochim. Ac., 141, 97-112, 2014.

De Leeuw, J. W. and Baas, M.: Early-stage diagenesis of steroids, in: Biological markers in the sedimentary record, edited by: Johns, R. B., Elsevier, Amsterdam, 101-123, 1986.
Diefendorf, A. F. and Freimuth, E. J.: Extracting the most from terrestrial plant-derived $n$-alkyl lipids and their carbon isotopes from the sedimentary record: A review, Org. Geochem., 103, 121, 2017.

Dinel, H., Schnitzer, M., and Meyhus, G. R.: Soil lipids: Origin, nature, content, decomposition, and effect on soil physical properties, in: Soil Biochemistry, edited by: Bollag, J. M. and Stotzky, G., Marcel Dekker Inc., New York, 397-429, 1990.

Dove, H., Mayes, R., and Freer, M.: Effects of species, plant part, and plant age on the $n$-alkane concentrations in the cuticular wax of pasture plants, Aust. J. Agric. Res., 47, 1333-1347, 1996.

Dyson, W. G. and Herbin, G. A.: Variation in leaf wax alkanes in cypress trees grown in Kenya, Phytochemistry, 9, 585-589, 1970.

Eckmeier, E. and Wiesenberg, G. L. B.: Short-chain nalkanes $\left(\mathrm{C}_{16-20}\right)$ in ancient soil are useful molecular markers for prehistoric biomass burning, J. Arch. Sci., 36, 1590-1596, 2009.

Eglinton, G., Gonzalez, A. G., Hamilton, R. J., and Raphael, R. A.: Hydrocarbon constituents of the wax coatings of plant leaves: A taxonomic survey, Phytochemistry, 1, 89-102, 1962a.

Eglinton, G., Hamilton, R. J., and Martin-Smith, M.: The alkane constituents of some New Zealand plants and their possible taxonomic implications, Phytochemistry, 1, 137-145, 1962b.

Ernst, N., Peterse, F., Breitenbach, S. F. M., Syiemlieh, H. J., and Eglinton, T. I.: Biomarkers record environmental changes along an altitudinal transect in the wettest place on Earth, Org. Geochem., 60, 93-99, 2013.

FAO: Guidelines for soil description, 4th Edn., Food and Agricultural Organization of the United Nations, Rome, Italy, 2006.

Feng, X. and Simpson, M. J.: The distribution and degradation of biomarkers in Alberta grassland soil profiles, Org. Geochem., 38, 1558-1570, 2007.

Feng, X., Xu, Y., Jaffé, R., Schlesinger, W. H., and Simpson, M. J.: Turnover rates of hydrolysable aliphatic lipids in Duke Forest soils determined by compound specific ${ }^{13} \mathrm{C}$ isotopic analysis, Org. Geochem., 41, 573-579, 2010.

Flessa, H., Amelung, W., Helfrich, M., Wiesenberg, G. L. B., Gleixner, G., Brodowski, S., Rethemeyer, J., Kramer, C., and Grootes, P. M.: Storage and stability of organic matter and fossil carbon in a Luvisol and Phaeozem with continuous maize cropping: A synthesis, J. Plant Nutr. Soil Sc., 171, 36-51, 2008.

Frostegard, A. and Bååth, E.: The use of phospholipid fatty acid analysis to estimate bacterial and fungal biomass in soil, Biol. Fert. Soils, 22, 59-65, 1996.

Gleixner, G.: Soil organic matter dynamics: a biological perspective derived from the use of compound-specific isotopes studies, Ecol. Res., 28, 683-695, 2013.

Gocke, M., Kuzyakov, Y., and Wiesenberg, G. L. B.: Differentiation of plant derived organic matter in soil, loess and rhizoliths based on $n$-alkane molecular proxies, Biogeochemistry, 112, 2340, https://doi.org/10.1007/s10533-011-9659-y, 2013.

Gocke, M., Peth, S. and Wiesenberg, G. L. B.: Lateral and depth variation of loess organic matter overprint related to rhizoliths - Revealed by lipid molecular proxies and X-ray tomography, Catena, 112, 72-85, 2014.

Gocke, M. I., Kessler, F., van Mourik, J. M., Jansen, B., and Wiesenberg, G. L. B.: Paleosols can promote root growth of recent vegetation - a case study from the sandy soil- 
sediment sequence Rakt, the Netherlands, SOIL, 2, 537-549, https://doi.org/10.5194/soil-2-537-2016, 2016.

González-Pérez, J. A., González-Vila, F. J., Almendros, G., and Knicker, H.: The effect of fire on soil organic matter - a review, Environ. Internat., 30, 855-870, 2004.

Grandmougin-Ferjani, A., Dalpé, Y., Hartmann, M., Laruelle, F., and Sancholle, M.: Sterol distribution in arbuscular mycorrhizal fungi, Phytochemistry, 50, 1027-1031, 1999.

Griepentrog, M., Bodé, S., Boeckx, P., Hagedorn, F., Heim, A., and Schmidt, M. W. I.: Nitrogen deposition promotes the production of new fungal residues but retards the decomposition of old residues in forest soil fractions, Global Change Biol., 20, 327340,2014

Griepentrog, M., Eglinton, T. I., Hagedorn, F., Schmidt, M. W. I., and Wiesenberg, G. L. B.: Interactive effects of elevated $\mathrm{CO}_{2}$ and nitrogen deposition on fatty acid molecular and isotope composition of above- and belowground tree biomass and forest soil fractions, Global Change Biol., 21, 473-486, 2015.

Griepentrog, M., Bodé, S., Boeckx, P., and Wiesenberg, G. L. B.: The fate of plant wax lipids in a model forest ecosystem under elevated $\mathrm{CO}_{2}$ concentration and increased nitrogen deposition, Org. Geochem., 98, 131-140, 2016.

Guggenberger, G., Zech, W., and Thomas, R. J.: Lignin and carbohydrate alteration in particle-size separates of an Oxisol under tropical pastures following native savanna, Soil Biol. Biochem., 27, 1629-1638, 1995.

Gülz, P. G. and Boor, G.: Seasonal variations in epicuticular wax ultrastructures of Quercus robur leaves, Z. Naturforsch. C, 47, 807-814, 1992.

Gülz, P. G. and Muller, E.: Seasonal variation in the composition of epicuticular waxes of Quercus robur leaves, Z. Naturforsch. C, 47, 800-806, 1992.

Gülz, P. G., Muller, E., and Prasad, R. B. N.: Developmental and seasonal variations in the epicuticular waxes of Tilia tomentosa leaves, Phytochemistry, 30, 769-773, 1991.

Hamer, U., Rumpel, C., and Dignac, M. F.: Cutin and suberin biomarkers as tracers for the turnover of shoot and root derived organic matter along a chronosequence of Ecuadorian pasture soils, Eur. J. Soil Sci., 63, 808-819, 2012.

Hamrouni, I., Ben Salah, H., and Marzouk, B.: Effects of waterdeficit on lipids of safflower aerial parts, Phytochemistry, 58, 277-280, 2001.

Hautevelle, Y., Michels, R., Malartre, F., and Trouiller, A.: Vascular plant biomarkers as proxies for palaeoflora and palaeoclimatic changes at the Dogger/Malm transition of the Paris Basin (France), Org. Geochem., 37, 610-625, 2006.

Heim, A. and Schmidt, M. W. I.: Lignin turnover in arable soil and grassland analysed with two different labelling approaches, Eur. J. Soil Sci., 58, 599-608, 2007.

Hellgren, L. I. and Sandelius, A. S.: Age-dependent variation in membrane lipid synthesis in leaves of garden pea (Pisum sativum L.), J. Exp. Bot., 52, 2275-2282, 2001.

Herbin, G. A. and Robins, P. A.: Studies on plant cuticular waxes I: The chemotaxonomy of alkanes and alkenes of the genus Aloe (Liliaceae), Phytochemistry, 7, 239-255, 1968.

Herbin, G. A. and Robins, P. A.: Patterns of variation and development in leaf wax alkanes, Phytochemistry, 8, 1985-1998, 1969.
Herbin, G. A. and Sharma, K.: Studies on plant cuticular waxes V. The wax coatings of pine needles: A taxonomic survey, Phytochemistry, 8, 151-160, 1969.

Hermann, N., Boom, A., Carr, A. S., Chase, B. M., West, A. G., Zabel, M., and Schefuss, E.: Hydrogen isotope fractionation of leaf wax $n$-alkanes in southern African soils, Org. Geochem., 109, 1-13, 2017.

Höfle, S., Rethemeyer, J., Mueller, C. W., and John, S.: Organic matter composition and stabilization in a polygonal tundra soil of the Lena Delta, Biogeosciences, 10, 3145-3158, 2013.

Huang, X., Wang, C., Zhang, J., Wiesenberg, G. L. B., Zhang, Z., and Xie, S.: Comparison of free lipid compositions between roots and leaves of plants in the Dajiuhu Peatland, central China, Geochem. J., 45, 365-373, 2011.

Huang, Y., Bol, R., Harkness, D. D., Ineson, P., and Eglinton, G.: Post-glacial variations in distributions, ${ }^{13} \mathrm{C}$ and ${ }^{14} \mathrm{C}$ contents of aliphatic hydrocarbons and bulk organic matter in three types of British acid upland soils, Org. Geochem., 24, 273-287, 1996.

Huang, Y., Eglinton, G., Ineson, P., Bol, R., and Harkness, D. D.: The effects of nitrogen fertilisation and elevated $\mathrm{CO}_{2}$ on the lipid biosynthesis and carbon isotopic discrimination in birch seedlings (Betula pendula), Plant Soil, 216, 35-45, 1999.

Jackson, R. B., Canadell, J., Ehleringer, J. R., Mooney, H. A., Sala, O. E., and Schulze, E. D.: A global analysis of root distributions for terrestrial biomes, Oecologia, 108, 389-411, 1996.

Jackson, R. B., Mooney, H. A., and Schulze, E. D.: A global budget for fine root biomass, surface area, and nutrient contents, P. Natl. Acad. Sci. USA, 94, 7362-7366, 1997.

Jaffe, R., Elisme, T., and Cabrera, A. C.: Organic geochemistry of seasonally flooded rain forest soils: Molecular composition and early diagenesis of lipid components, Org. Geochem., 25, 9-17, 1996.

Jambu, P., Fustec, E., and Jacquesy, R.: Les lipides des sols: nature, origine, evolution, propriétés, Science du Sol, 4, 229-240, 1978.

Jansen, B. and Nierop, K. G. J.: Me-ketones in high altitude Ecuadorian Andisols confirm excellent conservation of plant-specific $n$ alkane patterns, Org. Geochem., 40, 61-69, 2009.

Jansen, B., Nierop, K. G. J., Hageman, J. A., Cleef, A., and Verstraten, J. M.: The straight-chain lipid biomarker composition of plant species responsible for the dominant biomass production along two altitudinal transects in the Ecuadorian Andes, Org. Geochem., 37, 1514-1536, 2006.

Jansen, B., Nierop, K. G. J., Tonneijck, F. H., Van der Wielen, F. W. M., and Verstraten, J. M.: Can isoprenoids in leaves and roots of plants along altitudinal gradients in the Ecuadorian Andes serve as biomarkers?, Plant Soil, 291, 181-198, 2007.

Jansen, B., Van Loon, E. E., Hooghiemstra, H., and Verstraten, J. M.: Improved reconstruction of palaeo-environments through unravelling of preserved vegetation biomarker patterns, Palaeogeogr. Palaeocl., 285, 119-130, 2010.

Jansen, B., de Boer, E. J., Cleef, A. M., Hooghiemstra, H., MoscolOlivera, M., Tonneijck, F. H., and Verstraten, J. M.: Reconstruction of late Holocene forest dynamics in northern Ecuador from biomarkers and pollen in soil cores, Palaeogeogr. Palaeocl., 386, 607-619, 2013.

Kell, D. B.: Large-scale sequestration of atmospheric carbon via plant roots in natural and agricultural ecosystems: why and how?, Philos. T. Roy. Soc. B, 367, 1589-1597, 2012. 
Killops, S. D. and Frewin, N. L.: Triterpenoid Diagenesis and Cuticular Preservation, Org. Geochem., 21, 1193-1209, 1994.

Kim, K. S., Park, S. H., and Jenks, M. A.: Changes in leaf cuticular waxes of sesame (Sesamum indicum L.) plants exposed to water deficit, J. Plant Physiol., 164, 1134-1143, 2007.

Kindler, R., Miltner, A., Thullner, M., Richnow, H., and Kaestner, M.: Fate of bacterial biomass derived fatty acids in soil and their contribution to soil organic matter, Org. Geochem., 40, 29-37, 2009.

Kirkels, F. M., Jansen, B., and Kalbitz, K.: Consistency of plantspecific $n$-alkane patterns in plaggen ecosystems: A review, Holocene, 23, 1355-1368, 2013.

Knicker, H., Hilscher, A., De la Rosa, J. M., González-Pérez, J. A., and González-Vila, F. J.: Modification of biomarkers in pyrogenic organic matter during the initial phase of charcoal biodegradation in soils, Geoderma, 197-198, 43-50, 2013.

Koch, B., Harder, J., Lara, R. J., and Kattner, G.: The effect of selective microbial degradation on the composition of mangrove derived pentacyclic triterpenols in surface sediments, Org. Geochem., 36, 273-285, 2005.

Koch, K., Hartmann, K. D., Schreiber, L., Barthlott, W., and Neinhuis, C.: Influences of air humidity during the cultivation of plants on wax chemical composition, morphology and leaf surface wettability, Environ. Exp. Bot., 56, 1-9, 2006.

Kögel-Knabner, I.: The macromolecular organic composition of plant and microbial residues as inputs to soil organic matter, Soil Biol. Biochem., 34, 139-162, 2002.

Kramer, C. and Gleixner, G.: Variable use of plant- and soilderived carbon by microorganisms in agricultural soils, Soil Biol. Biochem., 38, 3267-3278, 2006.

Kreyling, J., Thiel, D., Simmnacher, K., Willner, E., Jentsch, A., and Beierkuhnlein, C.: Geographic origin and past climatic experience influence the response to late spring frost in four common grass species in central Europe, Ecography, 35, 268-275, 2012.

Krull, E., Sachse, D., Mügler, I., Thiele, A., and Gleixner, G.: Compound-specific $\delta^{13} \mathrm{C}$ and $\delta^{2} \mathrm{H}$ analyses of plant and soil organic matter: A preliminary assessment of the effects of vegetation change on ecosystem hydrology, Soil Biol. Biochem., 38, 3211-3221, 2006.

Ladygina, N., Dedyukhina, E. G., and Vainshtein, M. B.: A review on microbial synthesis of hydrocarbons, Process Biochem., 41, 1001-1014, 2006.

Larkindale, J. and Huang, B. R.: Changes of lipid composition and saturation level in leaves and roots for heat-stressed and heatacclimated creeping bentgrass (Agrostis stolonifera), Environ. Exp. Bot., 51, 57-67, 2004.

Lavrieux, M., Breheret, J., Disnar, J., Jacob, J., Le Milbeau, C., and Zocatelli, R.: Preservation of an ancient grassland biomarker signature in a forest soil from the French Massif Central, Org. Geochem., 51, 1-10, 2012.

Lavrieux, M., Jacob, J., LeMilbeau, C., Zocatelli, R., Masuda, K., Breheret, J., and Disnar, J.: Occurrence of triterpenyl acetates in soil and their potential as chemotaxonomical markers of Asteraceae, Org. Geochem., 42, 1315-1323, 2011.

Lehmann, J. and Kleber, M.: The contentious nature of soil organic matter, Nature, 528, 60-68, 2015.

Lei, B. K., Fan, M. S., Chen, Q., Six, J., and Zhang, F. S.: Conversion of wheat-maize to vegetable cropping systems changes soil organic matter characteristics, Science du Sol, 74, 1320-1326, 2010.

Lei, G., Zhang, H., Chang, F., Pu, Y., Zhu, Y., Yang, M., and Zhang, W.: Biomarkers of modern plants and soils from Xinglong Mountain in the transitional area between the Tibetan and Loess Plateaus, Quatern. Int., 218, 143-150, 2010.

Lejay, M., Alexis, M., Quénéa, K., Sellami, F., and Bon, F.: Organic signature of fireplaces: experimental references for archaeological interpretations, Org. Geochem., 99, 67-77, 2016.

Le Milbeau, C., Lavrieux, M., Jacob, J., Breheret, J., Zocatelli, R., and Disnar, J.: Methoxy-serratenes in a soil under conifers and their potential use as biomarkers of Pinaceae, Org. Geochem., 55, 45-54, 2013.

Li, H., Madden, L. J., and Potts, B. M.: Variation in leaf waxes of the Tasmanian Eucalyptus species 1. Subgenus Symphyomyrtus, Biochem. Syst. Ecol., 25, 631-657, 1997.

Li, J., Huang, J., Ge, J., Huang, X., and Xie, S.: Chemotaxonomic significance of $n$-alkane distributions from leaf wax in genus of Sinojackia species (Styracaceae), Biochem. Syst. Ecol., 49, 3036, 2013.

Lichtfouse, E., Berthier, G., Houot, S., Barriuso, E., Bergheaud, V., and Vallaeys, T.: Stable carbon isotope evidence for the microbial origin of $\mathrm{C}_{14}-\mathrm{C}_{18} n$-alkanoic acids in soils, Org. Geochem., 23, 849-852, 1995.

Lichtfouse, É., Bardoux, G., Mariotti, A., Balesdent, J., Ballentine, D. C., and Macko, S. A.: Molecular, ${ }^{13} \mathrm{C}$, and ${ }^{14} \mathrm{C}$ evidence for the allochthonous and ancient origin of $\mathrm{C}_{16}-\mathrm{C}_{18} n$-alkanes in modern soils, Geochim. Cosmochim. Ac., 61, 1891-1898, 1997.

Lichtfouse, É., Chenu, C., Baudin, F., Leblond, C., Da Silva, M., Behar, F., Derenne, S., Largeau, C., Wehrung, P., and Albrecht, P.: A novel pathway of soil organic matter formation by selective preservation of resistant straight-chain biopolymers: chemical and isotope evidence, Org. Geochem., 28, 411-415, 1998a.

Lichtfouse, E., Leblond, C., Da Silva, M., and Behar, F.: Occurrence of biomarkers and straight-chain biopolymers in humin: Implication for the origin of soil organic matter, Naturwissenschaften, 85, 497-501, 1998b.

Liebig, J., Merck, E., and Mohr, F.: Das aetherische Oel der Getraide, Ann. Pharmacie, 24, 248-251, 1837.

Liu, W., Yang, H., Ning, Y., and An, Z.: Contribution of inherent organic carbon to the bulk $\delta^{13} \mathrm{C}$ signal in loess deposits from the arid western Chinese Loess Plateau, Org. Geochem., 38, 15711579, 2007.

Lockheart, M. J., Poole, I., Van Bergen, P. F., and Evershed, R. P.: Leaf carbon isotope compositions and stomatal characters: important considerations for palaeoclimate reconstructions, Org. Geochem., 29, 1003-1008, 1998.

Luo, P., Peng, P., Gleixner, G., Zheng, Z., Pang, Z., and Ding, Z.: Empirical relationship between leaf wax $n$-alkane $\delta \mathrm{D}$ and altitude in the Wuyi, Shennongjia and Tianshan Mountains, China: Implications for paleoaltimetry, Earth Planet. Sc. Lett., 301, 285 296, 2011.

Maffei, M.: Discriminant analysis of leaf wax alkanes in the Lamiaceae and four other plant families, Biochem. Syst. Ecol., 22, 711-728, 1994.

Maffei, M.: Chemotaxonomic significance of leaf wax alkanes in the Gramineae, Biochem. Syst. Ecol., 24, 53-64, 1996a. 
Maffei, M.: Chemotaxonomic significance of leaf wax $n$-alkanes in the Umbelliferae, Cruciferae and Leguminosae (subf papilionoideae), Biochem. Syst. Ecol., 24, 531-545, 1996b.

Maffei, M., Mucciarelli, M., and Scannerini, S.: Environmentalfactors affecting the lipid-metabolism in Rosmarinus officinalis L., Biochem. Syst. Ecol., 21, 765-784, 1993.

Maffei, M., Meregalli, M., and Scannerini, S.: Chemotaxonomic significance of surface wax $n$-alkanes in the Cactaceae, Biochem. Syst. Ecol., 25, 241-253, 1997.

Maffei, M., Badino, S., and Bossi, S.: Chemotaxonomic significance of leaf wax $n$-alkanes in the Pinales (Coniferales), J. Biol. Res., 1, 3-20, 2004.

Malik, A., Blagodatskaya, E., and Gleixner, G.: Soil microbial carbon turnover decreases with increasing molecular size, Soil Biol. Biochem., 62, 115-118, 2013.

Mambelli, S., Bird, J. A., Gleixner, G., Dawson, T. E., and Torn, M. S.: Relative contribution of foliar and fine root pine litter to the molecular composition of soil organic matter after in situ degradation, Org. Geochem., 42, 1099-1108, 2011.

Marschner, B., Brodowski, S., Dreves, A., Gleixner, G., Gude, A., Grootes, P. M., Hamer, U., Heim, A., Jandl, G., Ji, R., Kaiser, K., Kalbitz, K., Kramer, C., Leinweber, P., Rethemeyer, J., Schäffer, A., Schmidt, M. W. I., Schwark, L., and Wiesenberg, G. L. B.: How relevant is recalcitrance for the stabilization of organic matter in soils?, J. Plant Nutr. Soil Sci., 171, 91-110, 2008.

Marseille, F., Disnar, J. R., Guillet, B., and Noack, Y.: n-Alkanes and free fatty acids in humus and $\mathrm{Al}$ horizons of soils under beech, spruce and grass in the Massif-Central (Mont-Lozere), France, Eur. J. Soil Sci., 50, 433-441, 1999.

Martelanc, M., Vovk, I., and Simonovska, B.: Determination of three major triterpenoids in epicuticular wax of cabbage (Brassica oleracea L.) by high-performance liquid chromatography with UV and mass spectrometric detection, J. Chrom. A, 1164, 145-152, 2007.

Matteucci, M., D’Angeli, S., Errico, S., Lamanna, R., Perrotta, G., and Altamura, M. M.: Cold affects the transcription of fatty acid desaturases and oil quality in the fruit of Olea europaea L. genotypes with different cold hardiness, J. Exp. Bot., 62, 3403-3420, 2011

Medina, E., Aguiar, G., Gomez, M., and Medina, J. D.: Patterns of leaf epicuticular waxes in species of Clusia: Taxonomical implications, Interciencia, 29, 579-582, 2004.

Medina, E., Aguiar, G., Gomez, M., Aranda, J., Medina, J. D., and Winter, K.: Taxonomic significance of the epicuticular wax composition in species of the genus Clusia from Panama, Biochem. Syst. Ecol., 34, 319-326, 2006.

Mendez-Millan, M., Dignac, M. F., Rumpel, C., and Derenne, S.: Quantitative and qualitative analysis of cutin in maize and a maize-cropped soil: Comparison of $\mathrm{CuO}$ oxidation, transmethylation and saponification methods, Org. Geochem., 41, 187-191, 2010a.

Mendez-Millan, M., Dignac, M.-F., Rumpel, C., Rasse, D. P., and Derenne, S.: Molecular dynamics of shoot vs. root biomarkers in an agricultural soil estimated by natural abundance ${ }^{13} \mathrm{C}$ labelling, Soil Biol. Biochem., 42, 169-177, 2010 b.

Mendez-Millan, M., Dignac, M., Rumpel, C., and Derenne, S.: Can cutin and suberin biomarkers be used to trace shoot and rootderived organic matter? A molecular and isotopic approach, Biogeochemistry, 106, 23-38, 2011.
Mendez-Millan, M., Dignac, M.-F., Rumpel, C., Rasse, D. P., Bardoux, G., and Derenne, S.: Contribution of maize root derived C to soil organic carbon throughout an agricultural soil profile assessed by compound specific ${ }^{13} \mathrm{C}$ analysis, Org. Geochem., 42, 1502-1511, 2012.

Mendez-Millan, M., Nguyen Tu, T. T., Balesdent, J., Derenne, S., Derrien, D., Egasse, C., Thongo M'Bou, A., Zeller, B., and Hatté, C.: Compound-specific ${ }^{13} \mathrm{C}$ and ${ }^{14} \mathrm{C}$ measurements improve the understanding of soil organic matter dynamics, Biogeochemistry, 118, 205-223, 2014.

Miltner, A., Bombach, P., Schmidt-Bruecken, B., and Kaestner, M.: SOM genesis: microbial biomass as a significant source, Biogeochemistry, 111, 41-55, 2012.

Moingt, M., Lucotte, M., and Paquet, S.: Lignin biomarkers signatures of common plants and soils of Eastern Canada, Biogeochemistry, 129, 133-138, 2016.

Mongrand, S., Badoc, A., Patouille, B., Lacomblez, C., Chavent, M., Cassagne, C., and Bessoule, J. J.: Taxonomy of gymnospermae: multivariate analysis of leaf fatty acid composition, Phytochemistry, 58, 101-115, 2001.

Moseley, G.: Variation in the epicuticular wax content of white and red clover leaves, Grass Forage Sci., 38, 201-204, 1983.

Moucawi, J., Fustec, E., Jambu, P., Ambles, A., and Jacquesy, R.: Biooxidation of added and natural hydrocarbons in soils: effect of iron, Soil Biol. Biochem., 13, 335-342, 1981a.

Moucawi, J., Fustec, E., Jambu, P., and Jacquesy, R.: Decomposition of lipids in soils: Free and esterified fatty acids, alcohols and ketones, Soil Biol. Biochem., 13, 461-468, 1981b.

Mueller-Niggemann, C. and Schwark, L.: Chemotaxonomy and diagenesis of aliphatic hydrocarbons in rice plants and soils from land reclamation areas in the Zhejiang Province, China, Org. Geochem., 83-84, 215-226, 2015.

Naafs, D. F. W., Van Bergen, P. F., Boogert, S. J., and de Leeuw, J. W.: Solvent-extractable lipids in an acid andic forest soil; variations with depth and season, Soil Biol. Biochem., 36, 297-308, 2004a.

Naafs, D. F. W., Van Bergen, P. F., de Jong, M. A., Oonincx, A. and de Leeuw, J. W.: Total lipid extracts from characteristic soil horizons in a Podzol profile, Eur. J. Soil Sci., 55, 657-669, 2004 b.

Ngosong, C., Gabriel, E., and Ruess, L.: Use of the Signature Fatty Acid 16:1 5 as a Tool to Determine the Distribution of Arbuscular Mycorrhizal Fungi in Soil, J. Lipids, 2012, 236807, https://doi.org/10.1155/2012/236807, 2012.

Nguyen Tu, T. T., Derenne, S., Largeau, C., Mariotti, A., and Bocherens, H.: Comparison of leaf lipids from a fossil ginkgoalean plant and its extant counterpart at two degradation stages: diagenetic and chemotaxonomic implications, Rev. Palaeobot. Palynol., 124, 63-78, 2003.

Nguyen Tu, T. T., Derenne, S., Largeau, C., Bardoux, G., and Mariotti, A.: Diagenesis effects on specific carbon isotope composition of plant $n$-alkanes, Org. Geochem., 35, 317-329, 2004.

Nguyen Tu, T. T., Egasse, C., Zeller, B., Bardoux, G., Biron, P., Ponge, J., David, B., and Derenne, S.: Early degradation of plant alkanes in soils: A litterbag experiment using ${ }^{13} \mathrm{C}$-labelled leaves, Soil Biol. Biochem., 43, 2222-2228, 2011.

Nierop, K. G. J. and Jansen, B.: Extensive transformation of organic matter and excellent lipid preservation at the upper, superhumid Guandera Páramo, Geoderma, 151, 357-369, 2009. 
Nierop, K. G. J. and Verstraten, J. M.: Rapid molecular assessment of the bioturbation extent in sandy soil horizons under, pine using ester-bound lipids by on-line thermally assisted hydrolysis and methylation-gas chromatography/mass spectrometry, Rapid Commun. Mass Spectrom., 18, 1081-1088, 2004.

Nierop, K. G. J., Van Lagen, B., and Buurman, P.: Composition of plant tissues and soil organic matter in the first stages of a vegetation succession, Geoderma, 100, 1-24, 2001.

Nierop, K. G. J., Jansen, B., Hageman, J. A., and Verstraten, J. M.: The complementarity of extractable and ester-bound lipids in a soil profile under pine, Plant Soil, 286, 269-285, 2006.

Nødskov Giese, B.: Effects of light and temperature on the composition of epicuticular wax of barley leaves, Phytochemistry, 14, 921-929, 1975.

Ohsaki, A., Shibata, K., Kubota, T., and Tokoroyama, T.: Phylogenetic and chemotaxonomic significance of diterpenes in some Portulaca species (Portulacaceae), Biochem. Syst. Ecol., 27, 289-296, 1999.

Otto, A. and Simpson, M. J.: Degradation and preservation of vascular plant-derived biomarkers in grassland and forest soils from Western Canada, Biogeochemistry, 74, 377-409, 2005.

Otto, A. and Simpson, M. J.: Sources and composition of hydrolysable aliphatic lipids and phenols in soils from western Canada, Org. Geochem., 37, 385-407, 2006.

Otto, A., Shunthirasingham, C., and Simpson, M. J.: A comparison of plant and microbial biomarkers in grassland soils from the Prairie Ecozone of Canada, Org. Geochem., 36, 425-448, 2005.

Pancost, R. D., Baas, M., Van Geel, B., and Damste, J. S. S.: Biomarkers as proxies for plant inputs to peats: an example from a sub-boreal ombrotrophic bog, Org. Geochem., 33, 675-690, 2002.

Peters, K. E., Walters, C. C., and Moldowan, J. M.: The Biomarker Guide, 2nd Edn., Cambridge University Press, Cambridge, UK, 2005.

Peterse, F., Van der Meer, M. T. J., Schouten, S., Jia, G., Ossebaar, J., Blokker, J., and Damste, J. S. S.: Assessment of soil $n$-alkane $\delta \mathrm{D}$ and branched tetraether membrane lipid distributions as tools for paleoelevation reconstruction, Biogeosciences, 6, 2799-2807, https://doi.org/10.5194/bg-6-2799-2009, 2009.

Peterse, F., Van der Meer, J., Schouten, S., Weijers, J. W. H., Fierer, N., Jackson, R. B., Kim, J., and Damste, J. S. S.: Revised calibration of the MBT-CBT paleotemperature proxy based on branched tetraether membrane lipids in surface soils, Geochim. Cosmochim. Ac., 96, 215-229, 2012.

Piervittori, R., Usai, L., Alessio, F., and Maffei, M.: Surface nalkane variability in Xanthoria parietina, Lichenologist, 28, 7987, 1996.

Prasad, R. B. N. and Gülz, P. G.: Developmental and seasonal variations in the epicuticular waxes of beech leaves (Fagus sylvatica L.), Z. Naturforsch. C, 45, 805-812, 1990.

Prost, K., Birk, J. J., Lehndorff, E., Gerlach, R., and Amelung, W.: Steroid biomarkers revisited - improved source identification of faecal remains in archaeological soil material, PLOS ONE, 12, e0164882, https://doi.org/10.1371/journal.pone.0164882, 2017.

Quenea, K., Derenne, S., Largeau, C., Rumpel, C., and Mariotti, A.: Variation in lipid relative abundance and composition among different particle size fractions of a forest soil, Org. Geochem., 35, 1355-1370, 2004.
Quenea, K., Largeau, C., Derenne, S., Spaccini, R., Bardoux, G., and Mariotti, A.: Molecular and isotopic study of lipids in particle size fractions of a sandy cultivated soil (Cestas cultivation sequence, southwest France): Sources, degradation, and comparison with Cestas forest soil, Org. Geochem., 37, 20-44, 2006.

Rao, Z., Zhu, Z., Jia, G., Henderson, A. C. G., Xue, Q., and Wang, S.: Compound specific $\delta \mathrm{D}$ values of long chain $n$-alkanes derived from terrestrial higher plants are indicative of the $\delta \mathrm{D}$ of meteoric waters: Evidence from surface soils in eastern China, Org. Geochem., 40, 922-930, 2009.

Rao, Z., Wu, Y., Zhu, Z., Jia, G., and Henderson, A.: Is the maximum carbon number of long-chain $n$-alkanes an indicator of grassland or forest? Evidence from surface soils and modern plants, Chinese Sci. Bull., 56, 1714-1720, 2011.

Rasse, D. P., Rumpel, C., and Dignac, M. F.: Is soil carbon mostly root carbon? Mechanisms for a specific stabilisation, Plant Soil, 269, 341-356, 2005.

Rethemeyer, J., Kramer, C., Gleixner, G., Wiesenberg, G. L. B., Schwark, L., Andersen, N., Nadeau, M. J., and Grootes, P. M.: Complexity of soil organic matter: AMS ${ }^{14} \mathrm{C}$ analysis of soil lipid fractions and individual compounds, Radiocarbon, 46, 465473, 2004.

Rommerskirchen, F., Eglinton, G., Dupont, L., Guntner, U., Wenzel, C., and Rullkotter, J.: A north to south transect of Holocene southeast Atlantic continental margin sediments: Relationship between aerosol transport and compound-specific $\delta^{13} \mathrm{C}$ land plant biomarker and pollen records, Geochem. Geophy. Geosci., 4, 1101, https://doi.org/10.1029/2003GC000541, 2003.

Rommerskirchen, F., Plader, A., Eglinton, G., Chikaraishi, Y., and Rullkoetter, J.: Chemotaxonomic significance of distribution and stable carbon isotopic composition of long-chain alkanes and alkan-1-ols in $\mathrm{C}^{4}$ grass waxes, Org. Geochem., 37, 1303-1332, 2006.

Rumpel, C. and Koegel-Knabner, I.: Deep soil organic matter - a key but poorly understood component of terrestrial C cycle, Plant Soil, 338, 143-158, 2011.

Sachse, D., Radke, J., and Gleixner, G.: $\delta$ D values of individual $n$-alkanes from terrestrial plants along a climatic gradient - Implications for the sedimentary biomarker record, Org. Geochem., 37, 469-483, 2006.

Sachse, D., Billault, I., Bowen, G. J., Chikaraishi, Y., Dawson, T. E., Feakins, S. J., Freeman, K. H., Magill, C. R., McInerney, F. A., Van der Meer, M. T. J., Polissar, P., Robins, R. J., Sachs, J. P., Schmidt, H., Sessions, A. L., White, J. W. C., West, J. B., and Kahmen, A.: Molecular paleohydrology: Interpreting the hydrogen isotopic composition of lipid biomarkers from photosynthesizing organisms, Annu. Rev. Earth Plant. Sci., 40, 221-249, 2012.

Sanchez, F. J., Manzanares, M., de Andres, E. F., Tenorio, J. L., and Ayerbe, L.: Residual transpiration rate, epicuticular wax load and leaf colour of pea plants in drought conditions. Influence on harvest index and canopy temperature, Eur. J. Agron., 15, 57-70, 2001.

Schefuß, E., Ratmeyer, V., Stuut, J. W., Jansen, J. H. F., and Sinninghe Damsté, J. S.: Carbon isotope analyses of $n$-alkanes in dust from the lower atmosphere over the central eastern Atlantic, Geochim. Cosmochim. Ac., 67, 1757-1767, 2003.

Schmidt, M. W. I., Torn, M. S., Abiven, S., Dittmar, T., Guggenberger, G., Janssens, I. A., Kleber, M., Koegel-Knabner, I., 
Lehmann, J., Manning, D. A. C., Nannipieri, P., Rasse, D. P., Weiner, S., and Trumbore, S. E.: Persistence of soil organic matter as an ecosystem property, Nature, 478, 49-56, 2011.

Schouten, S., Hopmans, E. C., and Sinninghe-Damsté, J. S.: The organic geochemistry of glycerol dialkyl glycerol tetraether lipids: A review, Org. Geochem., 54, 19-61, 2013.

Schreiber, L., Hartmann, K., Skrabs, M., and Zeier, J.: Apoplastic barriers in roots: Chemical composition of endodermal and hypodermal cell walls, J. Exp. Bot., 50, 1267-1280, 1999.

Shelvey, J. D. and Koziol, M. J.: Seasonal and $\mathrm{SO}_{2}$-induced changes in epicuticular wax of ryegrass, Phytochemistry, 25, 415-420, 1986.

Shepherd, T. and Griffiths, D. W.: The effects of stress on plant cuticular waxes, New Phytol., 171, 469-499, 2006.

Shepherd, T., Robertson, G. W., Griffiths, D. W., Birch, A. N. E., and Duncan, G.: Effects of environment on the composition of epicuticular wax from kale and swede, Phytochemistry, 40, 407417, 1995

Simpson, M. J. and Simpson, A. J.: The chemical ecology of soil organic Matter Molecular Constituents, J. Chem. Ecol., 38, 768784, 2012.

Simpson, M. J., Otto, A., and Feng, X.: Comparison of solid-state ${ }^{13} \mathrm{C}$ nuclear magnetic resonance and organic matter biomarkers for assessing soil organic matter degradation, Soil Sci. Soc. Am. J., 72, 268-276, 2008.

Sonibare, M. A., Jayeola, A. A., and Egunyomi, A.: Chemotaxonomic significance of leaf alkanes in species of Ficus (Moraceae), Biochem. Syst. Ecol., 33, 79-86, 2005.

Srivastava, K., Jentsch, A., Glaser, B., and Wiesenberg, G. L. B.: Plant and soil $n$-alkane composition is not affected by annual drought in temperate grassland and heathland ecosystems, J. Plant Nutr. Soil Sci., 180, 516-527, https://doi.org/10.1002/jpln.201600019, 2017.

Stevenson, F. J.: Lipids in soil, J. Am. Oil Chem., 43, 203-210, 1966.

Stevenson, F. J.: Humus Chemistry: Genesis, Composition, Reactions, John Wiley \& Sons, Inc., New York, 1994.

Stewart, C. E., Neff, J. C., Amatangelo, K. L., and Vitousek, P. M.: Vegetation effects on soil organic matter chemistry of aggregate fractions in a Hawaiian forest, Ecosystems, 14, 382-397, 2011.

Thevenot, M., Dignac, M., and Rumpel, C.: Fate of lignins in soils: A review, Soil Biol. Biochem., 42, 1200-1211, 2010.

Tissot, B. P. and Welte, D. H.: Petroleum Formation and Occurrence, 2nd Edn., Springer-Verlag, Berlin, Germany, 1984.

Tonneijck, F. H., Jansen, B., Nierop, K. G. J., Verstraten, J. M., Sevink, J., and De Lange, L.: Towards understanding of carbon stocks and stabilization in volcanic ash soils in natural Andean ecosystems of northern Ecuador, Eur. J. Soil Sci., 61, 392-405, 2010.

Tulloch, A. P.: Composition of leaf surface waxes of Triticum species: Variation with age and tissue, Phytochemistry, 12, 22252232, 1973.

Van Bon, L., Affandi, A. J., Broen, J., Christmann, R. B., Marijnissen, R. J., Stawski, L., Farina, G. A., Stifano, G., Mathes, A. L., Cossu, M., York, M., Collins, C., Wenink, M., Huijbens, R., Hesselstrand, R., Saxne, T., DiMarzio, M., Wuttge, D., Agarwal, S. K., Reveille, J. D., Assassi, S., Mayes, M., Deng, Y., Drenth, J. P. H., de Graaf, J., den Heijer, M., Kallenberg, C. G. M., Bijl, M., Loof, A., Van den Berg, W. B., Joosten, L. A. B., Smith,
V., de Keyser, F., Scorza, R., Lunardi, C., Van Riel, P. L. C. M., Vonk, M., Van Heerde, W., Meller, S., Homey, B., Beretta, L., Roest, M., Trojanowska, M., Lafyatis, R. and Radstake, T. R. D. J.: Proteome-wide Analysis and CXCL4 as a Biomarker in Systemic Sclerosis, N. Engl. J. Med., 370, 433-443, 2014.

Van Mourik, J. M. and Jansen, B.: The added value of biomarker analysis in palaeopedology; reconstruction of the vegetation during stable periods in a polycyclic driftsand sequence in SENetherlands, Quatern. Int., 306, 14-23, 2013.

Vogts, A., Moossen, H., Rommerskirchen, F., and Rullkoetter, J.: Distribution patterns and stable carbon isotopic composition of alkanes and alkan-1-ols from plant waxes of African rain forest and savanna $C^{3}$ species, Org. Geochem., 40, 1037-1054, 2009.

Volkman, J. K.: Sterols and other triterpenoids: source specificity and evolution of biosynthetic pathways, Org. Geochem., 36, 139-159, 2005.

Von Lützow, M., Kögel-Knabner, I., Ludwig, B., Matzner, E., Flessa, H., Ekschmitt, K., Guggenberger, G., Marschner, B. ,and Kalbitz, K.: Stabilization mechanisms of organic matter in four temperate soils: Development and application of a conceptual model, J. Plant Nutr. Soil Sci., 171, 111-124, 2008.

Wang, G., Huang, L., Zhao, X., Niu, H., and Dai, Z.: Aliphatic and polycyclic aromatic hydrocarbons of atmospheric aerosols in five locations of Nanjing urban area, China, Atmos. Res., 81, 54-66, 2006.

Weijers, J. W. H., Schouten, S., Spaargaren, O. C., and Damste, J. S. S.: Occurrence and distribution of tetraether membrane lipids in soils: Implications for the use of the TEX86 proxy and the BIT index, Org. Geochem., 37, 1680-1693, 2006.

Weijers, J. W. H., Bernhardt, B., Peterse, F., Werne, J. P., Dungait, J. A. J., Schouten, S., and Damste, J. S. S.: Absence of seasonal patterns in MBT-CBT indices in mid-latitude soils, Geochim. Cosmochim. Ac., 75, 3179-3190, 2011.

Wiesenberg, G. L. B. and Gocke, M.: Reconstruction of the late Quaternary paleoenvironments of the Nussloch loess paleosol sequence-Comment to the paper published by Zech et al., Quatern. Res., 79, 304-305, 2013.

Wiesenberg, G. L. B. and Schwark, L.: Carboxylic acid distribution patterns of temperate $C^{3}$ and $C^{4}$ crops, Org. Geochem., 37 , 1973-1982, 2006.

Wiesenberg, G. L. B., Schwarzbauer, J., Schmidt, M. W. I., and Schwark, L.: Source and turnover of organic matter in agricultural soils derived from $n$-alkane/ $n$-carboxylic acid compositions and C-isotope signatures, Org. Geochem., 35, 1371-1393, 2004.

Wiesenberg, G. L. B., Schmidt, M. W. I., and Schwark, L.: Plant and soil lipid modifications under elevated atmospheric $\mathrm{CO}_{2}$ conditions: I. Lipid distribution patterns, Org. Geochem., 39, 91-102, 2008a.

Wiesenberg, G. L. B., Schwarzbauer, J., Schmidt, M. W. I., and Schwark, L.: Plant and soil lipid modification under elevated atmospheric $\mathrm{CO}_{2}$ conditions: II. Stable carbon isotopic values $\left(\delta^{13} \mathrm{C}\right)$ and turnover, Org. Geochem., 39, 103-117, $2008 \mathrm{~b}$.

Wiesenberg, G. L. B., Lehndorff, E., and Schwark, L.: Thermal degradation of rye and maize straw: Lipid pattern changes as a function of temperature, Org. Geochem., 40, 167-174, 2009.

Wiesenberg, G. L. B., Schneckenberger, K., Kuzyakov, Y. ,and Schwark, L.: Plant lipid composition is not affected by shortterm isotopic $\left({ }^{13} \mathrm{C}\right)$ pulse-labelling experiments, J. Plant Nutr. Soil Sci., 172, 445-453, 2009. 
Wiesenberg, G. L. B., Schneckenberger, K., Schwark, L., and Kuzyakov, Y.: Use of molecular ratios to identify changes in fatty acid composition of Miscanthus x giganteus (Greef et Deu.) plant tissue, rhizosphere and root-free soil during a laboratory experiment, Org. Geochem., 46, 1-11, 2012.

Wiesenberg, G. L. B., Andreeva, D. B., Chimitdorgieva, G. D., Erbajeva, M. A., and Zech, W.: Reconstruction of environmental changes during the late glacial and Holocene reflected in a soil-sedimentary sequence from the lower Selenga River valley, Lake Baikal region, Siberia, assessed by lipid molecular proxies, Quatern. Int., 365, 190-202, 2015.

Williams, M., Shewry, P. R., and Harwood, J. L.: The influence of the Greenhouse-Effect on wheat (Triticum aestivum L.) Grain Lipids, J. Exp. Bot., 45, 1379-1385, 1994.

Williams, M., Shewry, P. R., Lawlor, D. W., and Harwood, J. L.: The effects of elevated temperature and atmospheric carbon dioxide concentration on the quality of grain lipids in wheat (Triticum aestivum $\mathrm{L}$ ) grown at 2 levels of nitrogen application, Plant Cell Environ., 18, 999-1009, 1995.

Williams, M., Robertson, E. J., Leech, R. M., and Harwood, J. L.: Lipid metabolism in leaves from young wheat (Triticum aestivum cv. Hereward) plants grown at two carbon dioxide levels, J. Exp. Bot., 49, 511-520, 1998.

Wöhler F. and Liebig, J.: Zusammensetzung einiger ätherischen Oele, Ann. Pharmacie, 32, 284-287, 1839.

Xie, M., Wang, G., Hu, S., Han, Q., Xu, Y., and Gao, Z.: Aliphatic alkanes and polycyclic aromatic hydrocarbons in atmospheric $\mathrm{PM}_{10}$ aerosols from Baoji, China: Implications for coal burning, Atmos. Res., 93, 840-848, 2009.

Zech, M., Buggle, B., Leiber, K., Marković, S., Glaser, B., Hambach, U., Huwe, B., Stevens, T., Sümegi, P., Wiesenberg, G., and Zöller: L.: Reconstructing Quaternary vegetation history in the Carpathian Basin, SE Europe, using $n$-alkane biomarkers as molecular fossils - Problems and possible solutions, potential and limitations, Quaternary Sci. J., 58, 148-155, 2009a.
Zech, M., Zech, R., Morras, H., Moretti, L., Glaser, B. and Zech, W.: Late Quaternary environmental changes in Misiones, subtropical NE Argentina, deduced from multi-proxy geochemical analyses in a palaeosol-sediment sequence, Quat. Internat., 196, 121-136, 2009b.

Zech, M., Leiber, K., Zech, W., Poetsch, T., and Hemp, A.: Late Quaternary soil genesis and vegetation history on the northern slopes of Mt. Kilimanjaro, East Africa, Quatern. Int., 243, 327 336, 2011.

Zeng, F., Xiang, S., Zhang, K., and Lu, Y.: Environmental evolution recorded by lipid biomarkers from the Tawan loess-paleosol sequences on the west Chinese Loess Plateau during the late Pleistocene, Environ. Earth Sci., 64, 1951-1963, 2011.

Zhang, Y., Togamura, Y., and Otsuki, K.: Study on the $n$-alkane patterns in some grasses and factors affecting the $n$-alkane patterns, J. Agric. Sci., 142, 469-475, 2004.

Zhang, Z. H., Zhao, M. X., Eglinton, G., Lu, H. Y., and Huang, C. Y.: Leaf wax lipids as paleovegetational and paleoenvironmental proxies for the Chinese Loess Plateau over the last $170 \mathrm{kyr}$, Quaternary Sci. Rev., 25, 575-594, 2006.

Zhou, J., Wang, T., Zhang, Y., Zhong, N., Medeiros, P. M., and Simoneit, B. R. T.: Composition and sources of organic matter in atmospheric $\mathrm{PM}_{10}$ over a two year period in Beijing, China, Atmos. Res., 93, 849-861, 2009.

Zocatelli, R., Lavrieux, M., Disnar, J., Le Milbeau, C., Jacob, J., and Breheret, J. G.: Free fatty acids in Lake Aydat catchment soils (French Massif Central): sources, distributions and potential use as sediment biomarkers, J. Soils Sediments, 12, 734-748, 2012. 